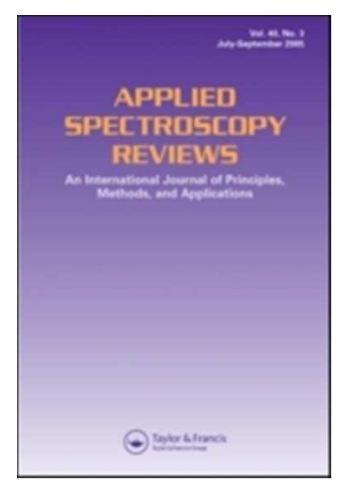

\title{
Determination of total petroleum hydrocarbon (TPH) and polycyclic aromatic hydrocarbon (PAH) in soils: a review of spectroscopic and non-spectroscopic techniques
}

\begin{tabular}{|r|l|}
\hline Journal: & Applied Spectroscopy Reviews \\
\hline Manuscript ID: & LAPS-2012-0046 \\
\hline Manuscript Type: & Reviews \\
\hline Date Submitted by the Author: & 22-Sep-2012 \\
\hline Keymlete List of Authors: & $\begin{array}{l}\text { Okparanma, Reuben; Cranfield University, Environmental Science and } \\
\text { Technology } \\
\text { Teuazen, Abdul; Cranfield University, Environmental Science and }\end{array}$ \\
\hline Techology \\
\hline
\end{tabular}

SCHOLARONE

Manuscripts 


\author{
Reuben Nwomandah Okparanma ${ }^{\text {a }}$ \\ a Department of Environmental Science and Technology, Cranfield University, Cranfield, \\ MK43 0AL Bedfordshire, United Kingdom. \\ Phone: +44 (0) $1234750111($ ext 2793) \\ E-mail: r.okparanma@cranfield.ac.uk \\ Reuben Nwomandah Okparanma is a PhD student in the Department of Environmental \\ Science and Technology, School of Applied Sciences, Cranfield University.
}

\begin{abstract}
Abdul Mounem Mouazen ${ }^{\text {a,* }}$
a Department of Environmental Science and Technology, Cranfield University, Cranfield, MK43 0AL Bedfordshire, United Kingdom.

Phone: +44 (0) $1234750111($ ext 2701)

Fax +44(0) 1234752971

E-mail: $\underline{\text { a.mouazen@cranfield.ac.uk }}$

*Corresponding Author

Abdul Mounem Mouazen, $\mathrm{PhD}$, is a Senior Lecturer and group leader of Agricultural Systems Engineering in the National Soil Resources Institute, Department of Environmental Science and Technology, Cranfield University. Dr. A. M. Mouazen holds a patent right of a tractor-drawn visible and near-infrared (vis-NIR) soil sensor for online proximal soil sensing.
\end{abstract}




\begin{abstract}
In the analysis of petroleum hydrocarbon-contaminated soils for total petroleum hydrocarbons (TPH) and polycyclic aromatic hydrocarbons (PAH), the role spectroscopic and non-spectroscopic techniques play are inseparable. Therefore, spectroscopic techniques cannot be discussed in isolation. In this report, spectroscopic techniques including Raman, fluorescence, infrared, visible-near-infrared spectroscopies, as well as mass spectroscopy (coupled to a gas chromatograph), and non-spectroscopic techniques such as gravimetric, immunoassay and gas chromatography with flame ionization detection are reviewed. To bridge the perceived gap in coverage of the quantitative applications of the vis-NIR spectroscopy in the rapid determination of TPHs and PAHs in soils, a detailed review of studies from the period 1999 - 2012 are presented. This report also highlights the strength and limitations of these techniques and evaluates their performance from the perspectives of their attributes of general applicability, namely: economic, portability, operational time, accuracy, and occupational health and safety considerations. Overall, the fluorescence spectroscopic technique had the best performance ( $85 \%$ total score) in comparison to others, while the gravimetric technique performed the least (60\% total score). Method-specific solutions geared towards performance improvement have also been suggested.
\end{abstract}

Key words: Petroleum-Hydrocarbons; Soil; Raman spectroscopy; IR spectroscopy; Fluorescence spectroscopy; Mass spectroscopy; Vis-NIR spectroscopy

\author{
Abbreviations: \\ COPC, constituents of potential concern; DRS, diffuse reflectance spectroscopy; EPA, \\ Environmental Protection Agency; FID, flame ionisation detection; GC, gas chromatography; \\ IMA, immunoassay; IR, infrared; MLR, multiple linear regression; MSD, mass selective \\ detector; MVA, multivariate analysis; PAH, polycyclic aromatic hydrocarbon; PLSR, partial
}




\section{Introduction}

In both the upstream and downstream sectors of the oil and gas industry, available records show that spillage of crude-oil and its daughter products occurs frequently due to natural and anthropogenic causes $(1,2)$. Crude-oil spill on land introduces petroleum-based hydrocarbons (PHCs), which negatively impact on soil biological, chemical and physical characteristics. Results of various environmental studies carried out in oil spill areas show staggering levels of environmental pollution and adverse effects on biota due to the hazardous nature of PHCs (e.g. 3-10). Prior to the remediation of the impacted media, a full assessment of the impact of the PHCs on the environment and/or humans is essential to identifying both the chemistry and the areal extent to which the PHCs exceed local threshold limit values (TLV), and providing decision support on the appropriate remedial strategy to adopt for effective clean-up of the environmental media. The hierarchical approach to risk assessment (11-20) reflects the different types of data handling required at each stage in the data gathering process. Whereas tier 1 risk assessment involves, but not limited to, the quantitation of the total petroleum hydrocarbons (TPH) and $n$-alkanes to establish their riskbased screening levels (RBSLs), tier 2 (i.e. generic quantitative risk assessment) involves the analysis of the proximal composition and distribution of individual polycyclic aromatic hydrocarbon $(\mathrm{PAH})$ fractions and the indicator PAH compounds. Tier 3 involves a more detailed investigation to determine the compound-specific biomarkers in the environmental sample (21). 
Over the years, several spectroscopic and non-spectroscopic techniques have been developed for the analysis of TPH and PAH in soil samples but, the most frequently used are immunoassay (IMA), general gravimetry, laboratory-based gas chromatography (GC) with flame ionisation detection (FID) or mass spectrometry (MS), infrared (IR) spectroscopy, Raman spectroscopy and fluorescence spectroscopy. In recent times, though, a couple of equally important innovative methods that has shown significantly reasonable potentials for the measurement of TPH and PAH in oil-contaminated soils is emerging. These include field portable GC/MS (22), and new generation near-infrared analysis (NIRA) with visible and near-infrared (vis-NIR) spectroscopy $(23-28)$. Although it was not until the recent past that some IMA techniques $(29,30)$, field portable GC/MS systems (22), and vis-NIR spectroscopy (28) were used to detect PAHs in soil samples. Before now, the laboratorybased GC/MS systems, fluorescence spectroscopy and Raman spectroscopy have been used for the analysis of PAH in environmental samples but, the GC/MS systems are mostly preferred because of their relative selectivity and sensitivity $(18,31-33)$.

It has been widely acknowledged that making informed decisions on remediation requirements after an oil spill incident requires information about hydrocarbon fractions. It also requires that the degree of accuracy achieved by different analytical techniques currently available meet given standards. This of course has to associate with sampling resolution and cost of analysis, as these are crucial factors for a successful evaluation of hydrocarbon contamination in soils. This may explain the spate of recent efforts to evolve innovative analytical techniques that are believed to be economical, rapid, less prone to occupational hazards and capable of high sampling resolution for improved contaminant mapping and refined soil remediation recommendation; even though they still complement the standard analytical techniques. Unfortunately, to our knowledge, there is no review at the moment on environmental diagnostic tools for TPH and PAHs in contaminated soils, which includes 


\section{Analytical techniques for petroleum hydrocarbons in soils}

No doubt, analytical methods for petroleum hydrocarbons currently in use are numerous and would be all too a herculean task to exhaust in one review. This is the reason this review focused on a selected number of the most frequently used traditional methods and innovative techniques including the vis-NIR spectroscopic method to drive home the aim of this report. These methods are distinguishable by the level of analytical details they provide and their method of application, into: screening techniques, conventional non-specific methods, and 
methods for detailed component analysis (36), which may be field- and/or laboratory-based. As earlier stated, there are several field- and laboratory-based analytical methods for petroleum hydrocarbons currently in use but, the most frequently used methods (Table 1) are gas chromatography with flame ionization detection (GC/FID) (EPA Method 8015) or mass spectrometric detection (GC/MSD) (EPA Methods 8270 and 625), infrared (IR) spectroscopy (EPA Method 418.1), petroleum hydrocarbons by immunoassay (IMA) (EPA Methods 4030 and 4035), and gravimetric TPH methods (EPA Method 1664). Others are Raman spectroscopy, fluorescence spectroscopy and vis-NIR spectroscopy.

\subsection{Laboratory-based techniques}

\subsubsection{General gravimetry}

Gravimetric methods employ an initial cold solvent extraction step and a final weightdifference step. In-between, though, there may be a further clean-up step with silica gel to remove biogenic material. If it does not involve a clean-up step, it is termed oil and grease $(\mathrm{O} \& \mathrm{G})$ method but, if it does, it is termed TPH method (31). In the general gravimetric TPH method (EPA Method 1664), soil samples are uniformly graded by sieving, oven-dried at 105 ${ }^{\circ} \mathrm{C}$ for 12 hours, and TPH compounds eluted with $n$-hexane. The liquid extract (eluate) is contacted with silica gel to remove biogenic polar materials and then evaporated. The residue is retained and weighed, and the weight difference is reported as a percent of the total soil sample on dry weight basis. Because of the presence of suspended solids, EPA Method 1664 recommends using a $0.45-\mu \mathrm{m}$ filter (31). Being among the earliest methods developed, though obviously one of the fast declining choice methods (37), gravimetric methods have been widely used to determine TPH in contaminated soils (37). Before now, gravimetric methods were described as quick and inexpensive methods but, in a recent study (37), the long time required for complete hexane evaporation, of not less than 60 minutes, "elevates 
the energetic costs of the overall procedure", and analytical losses at higher times that cause negative errors are incurred. The latter limitation corroborates similar findings in earlier studies $(36,38,39)$. The extraction efficiency of gravimetric methods, albeit poor, is hugely affected by the type of eluting solvent used $(36,40)$. Hexane has poor extraction efficiency for higher molecular weight petroleum compounds (31), and low polarity, which causes the co-extraction of natural organic matter containing multiple polar functional groups $(37,41)$. Consequently, other chlorinated compounds like chloroform (42) as well as toluene (43) have been used as liquid extractant. It is well known that both chloroform and toluene have serious health implications as evident in the risk phrases published in their respective safety data sheets. Additionally, gravimetric methods are non-specific since they give no information about the type of hydrocarbon present $(31,37)$. As a result, they are not suitable for assessing PAH compounds. Instead, the method is best suited for screening TPH in very oily sludges or samples containing very heavy molecular-weight hydrocarbons since light hydrocarbons (< $\mathrm{C}_{15}$ ) are easily volatilized at temperatures below 70 to $85^{\circ} \mathrm{C}$ during the evaporation step (31). Detection limits for TPH of approximately $50 \mathrm{mg} / \mathrm{kg}$ in soils have been reported (31).

\subsubsection{Infrared (IR) spectroscopy}

This method harnesses the spectra of the stretching and bending vibration associated with a molecule when it absorbs energy in the IR region of the electromagnetic spectrum for property elucidation (31). In the electromagnetic spectrum, spectra of hydrocarbon derivatives originate mainly from combinations or overtones of $\mathrm{C}-\mathrm{H}$ stretching modes of saturated $\mathrm{CH}_{2}$ and terminal $-\mathrm{CH}_{3}$ or aromatic $\mathrm{C}-\mathrm{H}$ functional groups (44). In the IR region, these occur within the wavenumber range of 3000 to $2900 \mathrm{~cm}^{-1}$ ( 3333 to $\left.3448 \mathrm{~nm}\right)$ or at the specific wavenumber of $2930 \mathrm{~cm}^{-1}(\sim 3413 \mathrm{~nm})(33)$. Usually, as-received samples are first extracted with an eluting solvent containing no $\mathrm{C}-\mathrm{H}$ bonds and the eluate is contacted with 
silica gel to remove biogenic polar components before being subjected to IR spectrometry. The absorbance of the eluate is then measured at the specified wavenumber and compared against the calibration curve developed for the instrument. The instrument calibration standard usually is a petroleum hydrocarbon of known TPH concentration (31). The primary advantage of the IR-based methods is that they are quick, simple and inexpensive with commonly detection limits of approximately $10 \mathrm{mg} / \mathrm{kg}$ in soil $(31,45)$.

Before the advent of gas chromatographic (GC)-based methods, IR-based methods were frequently used to detect TPH in soils (e.g. 46) as it was recognised by the USEPA as an official TPH screening method such as EPA Method 418.1 (36) as well as by the ISO as in ISO/TR 11046 (47). But, following the ban on the use of Freon (also known as 1,1,2trichlorotrifluoroethane $-\mathrm{CFE}$ ) as an extracting solvent because of its potentials to deplete the ozone layer, the use of IR-based methods has plummeted over the years (31). Despite the ban, though, a handful of studies can be found in the open literatures on the use of IR-based methods $(27,45,47)$. However, its use as a TPH measurement method is no longer supported by international standardisation; ISO for instance, has replaced ISO/TR 11046:1992 by ISO/DIS 16703:2001, which recommends the use of gas chromatography/flame ionization detection (GC/FID) after extraction with a halogen-free solvent (47). ISO/DIS 16703:2001 has been updated since 2004. Apart from the limitations on its use, a major constraint of the IR-based method, according to literatures $(36,48)$, is the insensitivity of the technique to unsaturated components of weathered hydrocarbons not exhibiting detectable adsorption bands at the monitoring wavelength. Additionally, the use of standard hydrocarbon mixture different from the contaminating oil for prior equipment calibration invariably does not produce true contaminant concentration since different hydrocarbons respond differently to IR spectroscopy, since single hydrocarbon oil may not be suitable as a universal calibration standard $(36,48)$. This is because the proportion of saturated and unsaturated hydrocarbon 


\subsubsection{Gas Chromatography/Flame Ionization Detection (GC/FID)}

The origin, principle and techniques of chromatography have been widely documented (e.g. 49). Succinctly, chromatography is a separation method in which a mixture is applied as a narrow initial zone to a stationary, porous sorbent and the components are caused to undergo differential migration by the flow of the mobile phase, a liquid or a gas (49). In gas chromatography, an inert carrier gas (helium, hydrogen or nitrogen) carries the gaseous mixture (or if aqueous, liquids with boiling points $<400{ }^{\circ} \mathrm{C}$ ), which is to be analysed, through a capillary column onto a detector at the end of the column $(31,49)$, which allows better resolution of components in complex mixtures.

In GC/FID method, as-received samples are first refrigerated at $4{ }^{\circ} \mathrm{C}$ until extraction, and dried either chemically (using a suitable drying agent, say anhydrous sodium sulphate) or physically, in an oven at $105{ }^{\circ} \mathrm{C}$ for 24 hours, to remove any residual moisture. TPH compounds in the dried samples are then extracted employing eluting solvents (e.g. acetone, dichloromethane, hexane or pentane), and different forms of adsorbents (e.g. silica gel, alumina or Florisil ${ }^{\circledR}$ ) are used for the extract clean-up and fractionation into aliphatics and 
aromatics (32) prior to injection into a chromatographic column. Sample extracts are introduced into the capillary column by headspace, purge-and-trap method (for volatile compounds in the rage $\mathrm{C}_{6}$ to $\mathrm{C}_{25}$ or $\mathrm{C}_{36}$ ) or direct injection method (for the less volatile fractions). As the temperature of the column is gradually raised, TPH compounds are separated according to their boiling points as they migrate towards the end of the column onto the flame ionization detector. In the detector, the high-concentration effluent eluting the column are trapped and ionized by burning them in a hydrogen-air or oxygen flame causing the gas in the detector to conduct electric current, and the conductivity is measured by a DCpowered collector electrode above the flame. The retention time of a compound prior to elution from the column is typical of the species under a set of conditions and is used to correlate the detector response to the amount of compound present. The detector responses in a given range are then integrated to give the total concentration of hydrocarbons referral to external and/or internal hydrocarbon standards $(31,49)$.

GC/FID is mostly preferred for laboratory applications as they provide relative selectivity and sensitivity (18, 31-33), and is recognised by the USEPA, BSI and ISO. The EPA Method 8015 is to be used to determine TPH, BS ISO 15009:2002 is for volatile aromatic and halogenated hydrocarbons, and BS ISO 16703:2004 is for the determination of content of hydrocarbons in the range $\mathrm{C}_{10}$ to $\mathrm{C}_{40}$ (n-alkanes), from solids including soils and wastes (50-53). GC/FID is used for both quantitative and qualitative applications including the screening of environmental samples (54-56), unravelling the type and identity of fresh to mildly weathered oil in environmental samples for pattern recognition of the petroleum hydrocarbons $(18,19)$, and characterising and resolving the profile of unresolved complex mixtures (UCM) in petroleum-contaminated sediments (57). The biodegradation rate constant of petroleum-hydrocarbons in a contaminated site is highly variable and difficult to evaluate due to variable site conditions. But, GC/FID has been used to develop a simple correlation 


\subsubsection{Gas Chromatography/Mass Spectrometry (GC/MS)}

Over the years, a couple of alternative detection techniques to the FID (Table 1) have been developed for more detailed analysis of a wider range of sample matrix due to the selectivity of the FID for hydrocarbons (32). The most prominently used is the mass spectrometric detection (MSD) technique. The MSD basically uses the characteristic mass spectra of molecular and/or fragmented ions produced after ion impact to identify compounds in the sample (62). The mass spectrometer has been described as a universal detector because of its versatility in the measurement of TPH, PAHs and the compound specific biomarkers (CSB) for a wide variety of environmental samples (63), and is recommended by the USEPA for the determination of both TPHs and PAHs (EPA Methods 8270 and 625). The popular choice of mass selective detector for most environmental analysis is because of its specificity and discrete monitoring capabilities; particularly when operated in the selective-ion mode (63). As part of its wide-reaching application, GC/MS has been used in environmental monitoring programmes to assess sediment quality in terms of concentration of total PAHs (64), to investigate the amount of PAHs in the topsoil of a tar-contaminated industrial site (65), for the fingerprinting analysis of some environmental sediments containing unsaturated priority PAHs [66], and to monitor the bioremediation of PAH-contaminated soil through invessel composting with fresh organic wastes (67). But, despite its widespread application, a 
major drawback of the GC/MS is that it requires volatile and thermally stable analytes; as such, only about $10 \%$ of organics are amenable to GC/MS analysis (68). More so, the MSD is reported to have a lower sensitivity than the FID, because in the impact ion mode, the respective detectors collect and measure different proportions of the generated molecular ions (63). Quantitative chemical analysis with laboratory-based GC/MS is undoubtedly very exhaustive but, like the GC/FID, involves lengthy and labour-intensive extraction protocols, costly GC-based analysis, and is uneconomical in the assessment of large-scale contamination involving dense sampling for mapping of zones requiring remediation (64).

\subsection{Field-based techniques}

\subsubsection{Immunoassays (IMA)}

IMA is a field-based immunochemical method in which antibodies are used to selectively bind specific petroleum constituents (31). The underlying principle of the IMA methods is variable; depending on the linked label used for response detection. The most prominent are: enzyme-linked immunosorbent assay (ELISA), fluorescence immunoassay and electrochemical immunoassay (ECIA).

In the ELISA method, the response of an antibody to sorb the sample analyte in relation to the enzyme-labelled analyte is determined by its optical density at sorption equilibrium. The concentration of the analyte in the sample is inversely related to the optical density of the antibody since the labelled enzyme, with high antibody affinity, is more sensitive to the colouring agent (31). Currently, there are a number of commercially available ELISA test kits including Ensys ${ }^{\mathrm{TM}}$ and RaPID ${ }^{\mathrm{TM}}$ assay (Strategic Diagnostics Newark, USA). Ensys ${ }^{\mathrm{TM}}$ is less sensitive to heavier hydrocarbon components usually found in weathered oils (45). $\mathrm{RaPID}^{\mathrm{TM}}$ assay has been used for the measurement of polycyclic aromatic hydrocarbons (PAHs) in soil (68) and electrical transformer oil (69) but, according to a recent study (70), is 
prone to the problem of cross-reactivity. Cross-reactivity, which is the ability to respond to compounds structurally similar to the analyte, affects the specificity of PAH immunoassays and often results in biased results because PAHs are a class of structurally related compounds (70). As a result, the ELISA test kits are unsuitable for risk-based studies, which involve the assessment of PAHs in the medium. They are, however, recognised by the USEPA as official screening methods for TPH (EPA Method 4030) and PAHs (EPA Method 4035).

Fluorescence immunoassay is based on selective antigen-antibody binding and fluorescence label reagents (31) and its use for the screening of aromatics in mainly water samples is widespread (45). Regardless of the media, it is important to note that fluorescence immunoassay also suffers the same cross-reactivity problems as the ELISA test kits as reports show that about $15 \%$ cross-reactivities of the anti-Naphthalene antibody bound to seven structurally related compounds are observed during the screening of Naphthalene in water samples with fluorescence immunoassay (29). This problem is even more complex in realworld situation since potential cross-reactants are unlimited in number and most are seldom determinable; so all cross-reactivity values for the cross-reactants for PAH immunoassays is all too difficult to determine (70).

Redox-labelled electrochemical immunoassay (ECIA) is a direct competitive immunoassay based on surface-immobilized anti-PAH monoclonal antibody and electrocatalytic redox-labelled tracer recently developed for Benzo[a]pyrene measurement (30). Although, detection limit of a $2.4 \mathrm{ng} / \mathrm{mL}$ was reported, it has been observed not sufficient for most practical applications. Additionally, cross-reactivity is not peculiar to polyclonal immunoassays but, is also a major challenge for monoclonal immunoassays (70) including redox-labelled ECIA; suggesting that ECIA also suffers the same fate as both ELISA test kits and fluorescence immunoassay. On top of these, it has been reported that immunoassay test 
methods are affected by soil matrix, age of weathered oil, and that their sensitivity to hydrocarbons decreases with increasing soil clay content (31).

\subsubsection{Fluorescence spectroscopy}

Fluorescence spectroscopy is a spectrochemical method of analysis in which the molecules of the analyte emit longer wavelength radiation in less than a microsecond during the process of relaxation to lower energy after excitation (Figure 1) by an incident shorter wavelength radiation.

Qualitative and quantitative information about the analyte is provided by the characteristic emission spectrum produced (71). It is a field portable technique that has been used to detect fluorescent compounds like the PAHs based on the principle that the intensity of the emitted radiation is indicative of the relative concentration of the $\mathrm{PAH}$ as well as the number of aromatic rings. Petroleum hydrocarbon molecules absorb energy in the wavelength range of 200 to $400 \mathrm{~nm}$ and fluoresce in the range 280 to $500 \mathrm{~nm}$ with each molecule fluorescing at a specific wavelength thereby enabling the possibility of differentiating between the various molecular classes (72). Monocyclic aromatic hydrocarbons (MAHs) fluoresce at lower wavelengths than the PAHs whereas the lower boiling PAHs such as Naphthalene fluoresce at lower wavelengths than the higher boiling PAHs like Benzo $[a]$ pyrene (72). Some commonly used fluorescence spectroscopic methods include the ultraviolet-induced fluorescence (UVIF) and Rapid Optical Screening Tool (ROST ${ }^{\mathrm{TM}}$ ) laserinduced fluorescence (LIF).

The UVIF employs a powerful UV lamp, which energises the hydrocarbons on illumination thereby causing them to fluoresce. The fluorescence signal is detected with a charge coupled device (CCD) camera, a polychromator (or a combination of both) or a silicon intensified target (SIT) camera. Most application utilise cone penetrometer technology 
(CPT). The CPT enables continuous measurement over the subsurface media of the investigation; providing semi-quantitative measurements (22). In one report, the United States Environmental Protection Agency (USEPA) has reported an average analysis time of 2.6 minutes and a detection limit of $3.4 \mathrm{mg} / \mathrm{kg}$ for field TPH measurement with the UVF3100A device (73). Using the QED $^{\text {TM }}$ hydrocarbon analyser designed by QROS $^{\circledR}$, even lower detection limits of $1 \mathrm{mg} / \mathrm{kg}$ in soils for petroleum fuels and oils and $0.1 \mathrm{mg} / \mathrm{kg}$ for PAHs in soil can be achieved in a single 5-second analysis with a throughput capacity of up to 15 samples per hour (72). Currently, in the US state of North Carolina, the QED ${ }^{\mathrm{TM}}$ hydrocarbon analyser has been approved as a replacement for the USEPA method 8015 (based on GC/FID) for monitoring remediation of fuel spills from Leaking Underground Storage Tanks (LUST) (72). Despite the quantitative strength of the UVIF, analysis of complex samples can be difficult due to overlap of spectra of different luminescent compounds, and prior sample extraction is required (22).

The ROST ${ }^{\mathrm{TM}}$ LIF system is a tunable dye laser-induced fluorescence system designed as a field screening tool for detecting petroleum hydrocarbons in the subsurface (74). Unlike the UVIF, the ROST ${ }^{\mathrm{TM}}$ LIF system uses a pulsed laser to cause fluorescence in PAH compounds instead of UV light. The laser is transmitted through a lorry-mounted CPT probe (housing a sapphire window) via excitation and emission optical fibres that are pushed into the ground (74). Available TPH data showed that the ROST ${ }^{\mathrm{TM}}$ LIF system can achieve an accuracy of $89.2 \%$ with false negatives and positives put at $5.4 \%$ respectively, and a limit of detection (LOD) of $5 \mathrm{mg} / \mathrm{kg}$ in soil (74). However, using PLS regression analysis, Aldstadt et al (71) reported sufficiently close match between predicted and measured PAHs for the technique to be used as a screening tool for all but 3 (i.e. Acenaphthylene, Dibenzo[a,h]Anthracen and Naphthalene) of the 16 priority PAHs. The ROST ${ }^{\mathrm{TM}}$ LIF system is designed for qualitative applications as it can only detect the presence or absence or relative concentration of 
contaminants, sensitive to non-hydrocarbon compounds in the soil, and its sensitivity is affected by soil matrix (22).

\subsubsection{Field portable gas chromatograph/mass spectrometry (GC/MS)}

Prompted by the need to reduce costly delays associated with laboratory-based GC systems, their portable version is emerging. Currently, a variety of portable GC/MS systems exist including (among others) CT-1128 GC-MS (Constellation Technology Corp., USA), HAPSITE (INFICON, USA), and EM 640 (Bruker Instruments, USA). Reported average weight of the portable GC systems is between 16 and $60 \mathrm{~kg}$ and typical analysis run time is less than 10 minutes for some models (75). The field portable GC/MS systems obviously differ from their laboratory-based counterparts (discussed later) in terms of provision of realtime quantification. They however, require prior sample extraction, on-site carrier gas, considerable electrical power and ancillary equipment just like the laboratory-based GC systems (22). Some analysts have also observed that the major problem with existing portable GC and GC/MS instruments, especially the microchip GCs, is sensitivity (75). A trade off appears to exist between the size and performance of the GC/MS instruments such that the smaller the portable GC or GC/MS instrument are, the greater the sacrifice in sensitivity, separating power, and identifying power (75). Thus, according to Harris (75), there will always be a place for the bench-top instrument for routine high-throughput, high-volume analysis.

\subsubsection{Raman spectroscopy}

Raman spectroscopy is a vibrational spectroscopy based on the inelastic scattering (Anti Stokes) of a monochromatic light source (Figure 2), usually from a laser source, used in 
assessing the vibration of Raman-active molecules such as the PAHs and for identifying species.

The Raman signal is detected with a charge coupled device (CCD) camera. Applications of Raman spectroscopy have been widely reviewed (76), and Raman spectral data for several PAHs have also been widely reported (77). In general, Raman spectroscopy is one of the RMTs that have made it possible to obtain high quality spectra on a time scale that is economical for analytical work (77). It suffices to say that Raman is both qualitative (78) and quantitative (79) in its application. However, extreme care is needed to avoid laser alteration of samples (80), and fluorescence contamination is often a problem with some Raman-based systems (79). More so, in all Raman instrument, noise is present to some extent and is a limiting factor in detection since it defines the detection limit of a particular compound (81). It has also been observed that although the miniaturisation of the Raman instrument enhances convenience, this has often come at a price as sensitivity; spectral range and spectral resolution are sacrificed with possible negative consequences to materials identification and verification (81).

\subsubsection{Visible and near-infrared (vis-NIR) spectroscopy}

The historical perspectives, fundamental principles and practical applications of NIR spectroscopy have been widely reported in the literatures (82). In NIR spectroscopy, absorption of energy by substances is due to overtones and combinations of fundamental vibrations that occur in the mid infrared range (MIR) based on the stretching and bending of bonds involving hydrogen and other atoms such as $\mathrm{C}-\mathrm{H}, \mathrm{O}-\mathrm{H}, \mathrm{N}-\mathrm{H}$ and $\mathrm{S}-\mathrm{H}$ chemical bonds (82). Although, much of the early applications of NIR spectroscopy were for qualitative purposes in the foods and beverages industry (82), its earliest qualitative and quantitative applications in soil science predominantly for agricultural purposes were reported in the 
1980's (83). Towards the end of the same period, the spectral characteristics of hydrocarbons were reported by Cloutis (84). The spectra of hydrocarbons originate mainly from combinations or overtones of $\mathrm{C}-\mathrm{H}$ stretching modes of saturated $\mathrm{CH}_{2}$ and terminal $\mathrm{CH}_{3}$, or aromatic C-H functional groups (44).

For the purpose of this study however, only the quantitative cases regarding detection of TPHs and PAHs in soils are reviewed. A comprehensive review of non-invasive NIR spectroscopy involving several other processes and matrixes can be found in Workman (85) and Schwartz et al. (86). Following Cloutis' work, by mid-1990's a fibre-optic NIR reflectance sensor for the detection of organics, such as Benzene and Toluene, in soils has been developed and tested (87). Consolidating on the outcome of those investigations, albeit reportedly dismal, a small-scale study was initiated to investigate the applicability of reflectance spectroscopy $(1600-1900 \mathrm{~nm})$ on sandy loam artificially contaminated with motor oil (88). Two years later, a relatively more comprehensive study was conducted involving three soil types artificially contaminated with diesel and gasoline with reported minimum detection limits of 0.1 and $0.5 \%$ by weight respectively (89). Away from the norm, Malley et al. (25) for the first time used NIR reflectance spectroscopy $(1100-2498 \mathrm{~nm})$ and the stepwise multiple linear regression to predict concentrations of TPH in dieselcontaminated soils collected from the field with low accuracy and high prediction error (Table 4). This low performance was attributed to the small number of sample set used and the inconsistency in the reference laboratory results (among others). A decade later, using different calibration models, Chakraborty et al. (26) reported fair TPH validation $\mathrm{R}^{2}$ for fieldcollected intact soils from oil-spill sites with vis-NIR reflectance spectroscopy (Table 4). They acknowledged that small number of sample set resulted in the failure to develop robust calibration models. The possibility of using vis-NIR spectroscopy $(400-2500 \mathrm{~nm})$ in reflectance mode as a RMT for TPH in crude oil- and diesel-spiked soil minerals (kaolinite, 
illite, smectite, carbonate and quartz) has also been reported by Forrester et al. (27) with relatively high calibration errors for some of the minerals (Table 4)._Bray et al. (28) used an ordinal logistic regression technique for total PAH and benzo[ $[a]$ pyrene predictions using visNIR spectroscopy with good accuracy and moderate to high false positive rate at low and high total PAH threshold respectively (Table 4). These results were attributed to a lack of samples. In 2012, three studies were reported $(90$ - 92) utilising laboratory-constructed hydrocarbon contaminated soil samples. Using several multivariate techniques and slightly higher number of sample set, Chakraborty et al. (90) predicted with significantly improved accuracy the amount of petroleum contamination in soil samples with vis-NIR spectroscopic method (Table 4). Schwartz et al. (91) employed several petroleum hydrocarbons (PHCs) for the simulated contamination of a total of 750 soil samples and used vis-NIR spectroscopic method to predict their TPH levels using PLS with unsatisfactory accuracy but good correlation results; a development they also attributed to the confirmed inter- and intralaboratory inconsistencies in reference TPH results. The third study predicted PAHs in sets of artificially contaminated soils with vis-NIR diffuse reflectance spectroscopy (the second study on PAH to be reported in two years) with reported reasonably high accuracy levels as shown in Table 4 (92).

It must be pointed out, however, that the interaction of NIR radiation with soil sample produces soil spectra with fewer absorption features due to weak vibrational modes of molecular functional groups, broad and overlapping bands, which make NIR spectra difficult to interpret (93). This is besides the long pathlength of probe, which may decrease resolution and accuracy of the vis-NIR spectroscopic method. However, intensive research is being conducted today to improve the accuracy of vis-NIR spectroscopy. 


\section{Integration, analysis and discussion}

When comparing technologies for the analysis of TPH and/or PAH in contaminated soils, several important attributes of general applicability can be used. In this review, the attributes discussed include economic considerations, operational time, occupational health and safety, portability and accuracy.

\subsection{Economic considerations}

The current capital equipment cost of different TPH and/or PAH analytical devices are shown in Table 2, which shows that the laboratory-based GC systems appear to be the most expensive probably due to their size and sophistication. Although the capital equipment cost of the portable EM 640 system is relatively on the high side, the capital equipment cost of the bench-top zNose ${ }^{\mathrm{TM}} 4200$ or portable 3000 Micro GC 1-, 2-channel systems is comparatively low (Table 2). The capital cost of the NIR-based systems is much lower than the laboratorybased GC systems and portable EM 640 model. It is about the same range as the portable IRbased system, and ExoScan 4100, but higher than those of IMA, fluorescence, portable Raman spectroscopic and GC-MS systems (Table 2). In terms of analytical cost, a standard PAH or TPH analysis by GC-based method currently costs $\sim £ 100$ per sample whereas the cost by the IR-based method is $\sim £ 32$ per sample in a commercial laboratory in a developing country such as Nigeria, which is equivalent to the cost for a similar analysis in most developed countries like the United Kingdom (UK) way back in 2005 (21). Currently in the $\mathrm{UK}$, it is possible that this cost may have increased considering the present economic realities. Analysts have always attributed this to the constantly increasing running cost of the GC-based systems. It is known that the analytical costs for most alternative methods, such as the FS-based systems, increase as the number of samples analysed decrease as a result of the spread of the initial capital equipment cost across the number of samples in contrast to the 


\subsection{Operational time}

Cycle time is the time it takes the analytical system to go from one analysis to the next (75), whereas analysis run time is the sum of the cycle time and the time spent preparing the sample for analysis. Sample preparation has got both occupational health (discussed later) and economic implications. During microcosm studies, experience shows that costly delays can result from overhead expenses due to high analysis run time. As shown in Table 3, high analysis run time is associated with techniques requiring lengthy initial sample preparation particularly the laboratory-based GC techniques; suggesting that the methods are uneconomical in the assessment of large-scale contamination involving dense sampling as has been previously reported (64). The portable GC systems can compare favourably with the non-invasive devices in terms of cycle time (Table 3) but, still involve time consuming sample extraction protocols. Although current data for gravimetric method were not available for comparison, the analysis run time for the laboratory-based IR, fluorescence spectroscopic and sorption-based IMA methods that which also require sample preparation, is comparable to those of the non-invasive Raman and NIR spectroscopic techniques. Table 3 shows that the portable IR, Raman and NIR spectroscopic techniques tend to have shorter analysis run time, since little or no sample preparation is required, as compared to those methods that depend on prior sample extraction. The shorter analysis run time of the portable IR, Raman and NIR spectroscopic techniques makes them potentially better techniques for cost-effective 
assessment of large-scale contamination involving dense sampling, rapid decision making and accurate contaminant mapping.

\subsection{Occupational health and safety}

As stated earlier, there are threatening occupational health and safety concerns associated with sample preparation. Preparing samples for TPH and/or PAH analysis with the gravimetric method [42, 43], IMA ELISA test kits $(68,95)$, laboratory-based IR spectroscopy (47), fluorescence spectroscopy (73) and GC-based methods (19) obviously involves handling of hydrocarbon-contaminated soil samples and noxious chlorinated extraction solvents, which exposes the user to potentially biological and chemical hazards. For instance, the solvent, tetrachloroethylene, often used as a substitute for Freon 113 for extracting TPH compounds for analysis with laboratory-based IR spectroscopy is a potential carcinogen according to the classification of the International Agency for Research on Cancer (IARC), and is also a central nervous system depressant, which finds its way into the human body through inhalation and skin contact (Wikipedia, The Free Encyclopedia). Similarly, dichloromethane (DCM), a liquid extractant for TPH and PAH analysis by GC-FID or GCMS, and chloroform and toluene, liquid extractants for TPH analysis by gravimetric method, all have serious health implications as evident in the risk phrases contained in their respective safety data sheets. Other equally dangerous chemicals (liquid or powder), which come in sealed bottles or bags that the operator must be exposed to when the containers are opened up during the making up of standard solution mixes for GC-based analysis are PAH and TPH calibration standards, internal standards such as deuterated alkanes and PAHs, and surrogate spike standards such as Squalane, $o$-Terphenyl, 2-Fluorobiphenyl, Heptamethylnonane etc.

On the other hand, the portable IR devices such as the Agilent ${ }^{\circledR} 4100$ ExoScan FTIR (96), the vis-NIR devices, fluorescence devices such as the UVF 3100 (73) and Raman 
devices employ electromagnetic radiation for property elucidation. In Raman spectroscopy, the electromagnetic radiation is capable of penetrating glass and plastic containers enabling in-vessel analysis thereby eliminating or reducing possible exposure to hazardous chemicals (97) but, operators still face possible exposure to fugitive lasers necessitating a Class 3B laser warning on the devices to comply with regulations. Even though the vis-NIR and portable IR devices employ particle physics in their applications, which eliminates the need for a liquid extractant and concomitant exposure to chemical hazard, there is still a need, according to their data sheets, for a close proximity between the sample and the detectors for better instrument sensitivities. This implies that possible contact with the contaminated soil sample and exposure to both biological and unknown hazards cannot be completely eliminated. In the same vein, fluorescence spectroscopy employing CCD (charge-coupled device) camera may still pose a radiation risk to the operator in addition to exposure to different proprietary extraction and calibration solvents often used during sample preparation.

\subsection{Portability}

Considering recent innovations, it appears that there is no clear-cut distinction between field- and laboratory-based techniques. Some techniques such as those based on IR, Raman and fluorescence spectroscopies, and the GC-based techniques, which are laboratory-based, are now also available in manageable sizes that can be deployed for field measurements and are now more user friendly (Table 3). For examples, with the coming on stream of the portable GC-MS devices (Table 3), and the portable IR systems such as the Agilent 4100 ExoScan FTIR (96) difficult circumstances can now be accessed in situ with relative ease. To the best of our knowledge, apart from the gravimetric methods, virtually all the techniques now come in field-implementable devices essentially for convenience and to also assuage the cost on logistics. However, it has been reported that miniaturisation of the GC-MS (75) and 
Raman (81) devices results in loss of instrument performance. However, we were not able to ascertain if this problem also affects the IR- and IMA-based techniques as well as the fluorescence and vis-NIR spectroscopic techniques. Field-portable devices in general, apart from being cost-effective, simple and easy to use, are meant to reduce the amount of time spent in conventional laboratory-based analysis, expedite the screening of contaminated sites to pave the way, if need be, for more detailed investigation (36).

\subsection{Accuracy}

More often than not, the performance of the standard analytical techniques is used as a benchmark for the innovative techniques because they are assumed to be very accurate when compared to the innovative methods. Consequently, the innovative techniques are seen to play a complementary role to the standard analytical techniques, and more so, as their data ultimately will have to be verified by the relevant standard analytical techniques such as the GC, IR spectroscopy, and general gravimetry (Table 4). The accuracy of an innovative analytical technique relative to a standard analytical method can be determined using different indicators (98). Although the root mean square error is commonly used for estimating the performance of NIR and IR techniques, it was not possible to be adopted since this was not reported while estimating the accuracy of other methods discussed in this report. The correlation coefficient, $\mathrm{R}^{2}$, value is seen in this report as the common denominator among other indicators so far reported by previous researchers (Table 4) and was, therefore, used to fairly compare how good or badly a particular innovative technique has been able to predict TPH and/or PAH values relative to a chosen standard analytical method. For a fair comparison, though, average values of $\mathrm{R}^{2}$ were used, and for the vis-NIR technique, only validated values, $R_{p}^{2}$, were used (see Table 4). We assumed a $R^{2}$ value between 0.9 and 1.0 as an excellent correlation, $\mathrm{R}^{2}$ value between 0.8 and 0.89 to be a good correlation, $\mathrm{R}^{2}$ value 


\section{Overall performance and method-specific recommendations}

Overall, Table 5 shows that most of the analytical techniques compare very well with fluorescence spectroscopy topping the table, while the gravimetric method made it to the bottom of the table. Fluorescence spectroscopy has excellent records in $60 \%$ of the attributes but, a good operational time and a fair occupational health and safety records (Table 5), which suggest that improvements should be geared towards reducing or completely eliminating the need for prior sample preparation.

The IMA evidently is economical, portable and has good accuracy but, has only a fair record for operational time and health and safety issues (Table 5) due to dependence on solvent extraction. So, like every other solvent extraction-dependent method, the IMA would require (among others) an operating protocol that will be less dependent on, or independent of, chlorinated extraction solvents. Although the GC-based method has $65 \%$ in the overall assessment, its high accuracy is well depicted in Table 5. This low overall score obviously is not unconnected with the effects of the poor health and safety records and the fair economic 
and operational time factors. The portable GC/MS systems undoubtedly had a positive influence on the mobility of the method. However, the introduction of the portable GC/MS devices did not have much positive impact on the economic (based on capital equipment cost), operational time and health and safety concerns of the method. This is because the cost of most portable GC/MS devices is still relatively high (Table 5), and the method is still reliant on time consuming extraction protocols and the use of extraction solvents. Therefore, operating protocols that encourage the use of non-chlorinated solvents without compromising analyte recovery may well improve on its health and safety impacts, while instrument design that eliminates completely the need for prior sample extraction will definitely enhance timeliness. The gravimetric method is cheap and has an assumed excellent accuracy record, because it is assumed that standard methods are reference frames against which innovative methods are referred. But, this is a laboratory-based method with poor health and safety records and a fair operational time (Table 5) due to the extraction step involved. Therefore, the gravimetric method would require the same improvement recommended for other extraction-dependent analytical methods earlier stated.

The IR and vis-NIR spectroscopies performed equally well on the overall score sheet (Table 5). The significantly improved records of the IR spectroscopy may be attributed to the enhanced accuracy and portability of the method brought about by the introduction of the portable IR devices. On the other hand, the vis-NIR spectroscopy has excellent records in terms of portability and operational time, and good records in economic and health and safety standpoints (Table 5). However, the vis-NIR spectroscopy has only a fair accuracy record, which appears to be the least among other methods (Table 5). The reason for this is that NIR prediction is based on overtones and combinations of fundamental vibrations occurring in the mid IR region. Therefore, significant improvement on the accuracy of the vis-NIR spectroscopy is required. Possible solutions may include: the use of non-linear multivariate 
analytical methods such as artificial neural networks (ANN) as an alternative to PLS regression analysis, and understanding the effects of other affecting parameters (e.g. soil texture, moisture content and oil concentration) on soil diffuse reflectance spectra of contaminated soils. Soil properties have been predicted with higher accuracy with the ANN than the PLS regression analysis with the vis-NIR spectroscopy (99). Similarly, Mouazen et al. (100) and Mouazen et al. (101) have reported that soil texture and moisture content respectively, negatively affect the performance of NIR spectroscopy in the prediction of soil chemical properties. By sufficiently understanding the individual and combined effects of these three factors, it is expected to establish techniques to reduce or even eliminate the effects of these factors and thus lead to improved accuracy of calibration models developed to predict TPH and/or PAHs in petroleum hydrocarbon-contaminated soils. Laboratory- and field-scale studies to address these key areas are being undertaken by the authors.

\section{Conclusions}

On a regular basis, analytical techniques for TPH and/or PAHs in soils are being developed and diverse factors are coalescing to bring this about. Top on this list of factors is the increasingly persistent demand for more profitable and simple environmental diagnostic tools capable of generating reliable data on a time scale. From this study, it is obvious that there is seldom an analytical technique that is problem-free although, some are less problematic than others. This is why efforts have been made in this study to extract as much relevant information from the open access literature as possible on the application of vis-NIR spectroscopy in particular, and analytical techniques in general, in the detection of petroleum contamination in soils. If timeliness and operator health and safety are anything to go by, improved protocols aimed at completely eliminating the need for prior sample preparation and the use of chlorinated extraction solvents become a consequent tandem. This suggested 
method change should necessarily target the gravimetric, GC-based, IMA-based, and fluorescence spectroscopic techniques because of their low performance in those two attributes due to their dependence on lengthy sample preparation steps involving the use of chlorinated extraction solvents and proprietary extraction kits. Although the vis-NIR technique compares well with other techniques in terms of cost-effectiveness, timeliness, operator health and safety and portability, it was documented to be the least accurate. This has to do with the fact that NIR prediction is based on overtones and combinations of fundamental vibrations occurring in the mid IR region. However, if the individual and interaction effects of soil texture, moisture content and oil concentration on soil diffuse reflectance spectra and calibration models developed are well understood, and if non-linear analytical techniques such as the artificial neural network (ANN) or support vector machine (SVM) and others could be applied as alternatives to linear PLS regression analysis used so far in the literature, the accuracy of the method may be improved. These are pertinent research questions that need to be answered.

To this end, there always will be room for some breakthroughs in trying to improve on existing systems by scientists, and for some techniques to complement others. Therefore, there is a need for constant reviews of the progress being made to help scientists avoid duplicating efforts by re-inventing the wheel.

\section{Acknowledgements}

The authors are grateful to the Petroleum Technology Development Fund (PTDF), Nigeria, for funding this research through financial assistance in the form of doctoral studentship.

\section{References}

1. Atlas, R.M. (1981) Microbial degradation of petroleum hydrocarbons: An environmental perspective. Microbiol. Rev., 45: 180-209. 
2. Ebuehi, O.A.T., Abibo, I.B., Shekwolo, P.D., Sigismund, K.T., Adoki, A. and Okoro, I.C. (2005) Remediation of crude oil polluted soil by enhanced natural attenuation. J. Appl. Sci. Environ. Manage., 9: 103-106.

3. Teruhisa, K., Masahiro, N., Hiroshi, K., Tomoko, Y., Marine Life Research Group of Takeno and Ohwada, K. (2003) Impacts of the Nakhodka heavy-oil spill on an intertidal ecosystem: an approach to impact evaluation using geographical information system. Mar. Pollut. Bull., 47: 99-104.

4. Yamamoto, T., Nakaoka, M., Komatsu, T., Kawai, H., Marine Life Research Group of Takeno and Ohwada, K. (2003) Impacts by heavy-oil spill from the Russian tanker Nakhodka on intertidal ecosystems - recovery of animal community. Mar. Pollut. Bull., 47: 91-98.

5. Katayama, Y., Oura, T., Iizuka, M., Orita, I., Cho, K.J., Chung, I.Y. and Okada, M. (2003) Effects of spilled oil on microbial communities in a tidal flat. Mar. Pollut. Bull., 47: 8590.

6. Daka, E.R. and Ekweozor, I.K.E. (2004) Effect of size on the acute toxicity of crude oil to the Mangrove Oyster (Carasostrea gasar). J. Appl. Sci. Environ. Manage., 8: 19-22.

7. Jack I.R., Fekarurhobo, G.K., and Igwe, F.U. (2005) Determination of hydrocarbons levels in some marine organisms from some towns within the Rivers State of Nigeria. J. Appl. Sci. Environ. Manage., 9: 59-61.

8. Umechuruba, C.I. (2005) Health impact assessment of mangrove vegetables in an oil spilled site at the Bodo West Field in Rivers State, Nigeria. J. Appl. Sci. Environ. Manage., 9: 69-73.

9. Adedokun, O.M. and Ataga, A.E. (2006) Effects of crude oil and oil products on growth of some edible mushrooms. J. Appl. Sci. Environ. Manage., 10: 91-93.

10. Daniel-Kalio, L.A. and Pepple, S.F. (2006) Effect of Bonny Light crude oil pollution of soil on the growth of dayflower (Commelina benghalensis L.) in the Niger Delta, Nigeria. J. Appl. Sci. Environ. Manage., 10: 111-114.

11. Pollard, S.J.T., Kenefick, S.L., Hrudy, S.F., Fuhr, B.J., Holloway, L.R. and Rawluk, M. (1994) A tiered analytical protocol for the characterisation of heavy oil residues at petroleum-contaminated hazardous waste sites. In Analysis of soil contaminated with petroleum constituents, O’Shay, T.A. and Hoddinott, K. B. Eds. Am. Soc. Testing Mater., Philadelphia, PA, pp. 38-52.

12. Page, D.S., Boehm, P.D., Douglas, G.S. and Bence, A.E. (1995) Identification of hydrocarbon sources in the benthic sediments of Prince William Sound and the Gulf of Alaska following the Exxon Valdez spill. In Exxon Valdez oil spill: fate and effects in Alaska waters, Wells, P.G., Butler, J.N. and Hughs J.S. Eds. Am. Soc. Testing Mater., Philadelphia, PA, pp. 41-83.

13. Boehm, P.D., Page, D.S., Gilfillan, E.S., Bence, A.E., Burns, W.A. and Mankiewicz, P.J. (1998) Study of the fate and effects of the Exxon Valdez oil spill on benthic sediments in two bays in Prince William Sound, Alaska: 1. study design, chemistry and source fingerprinting. Environ. Sci. Technol., 32: 567-613.

14. Wang, Z.D., Fingas, M., Landriault, M., Sigouin, L., Grenon, S. and Zhang, D. (1999) Source identification of an unknown spilled oil from Quebec (1998) by unique biomarker and diagnostic ratios of source-specific marker compounds. Environ. Technol., 20: 851862.

15. Wang, Z.D., Fingas, M. and Sigouin, L. (2002) Using multiple criteria for fingerprinting unknown oil samples having very similar chemical composition. In Proceedings of the $25^{\text {th }}$ Arctic and Marine Oil Spill Program (AMOP) Technical Seminar: Environment Canada, Ottawa, Canada, pp. 639-660. 
16. Stout, S.A., Uhler, A.D., McCarthy, K.J., Emsbo-Mattingly, S. (2002) Chemical fingerprinting of hydrocarbons. In Introduction to Environmental Forensics, Murphy, B.L. and Morrison, R.D. Eds. Academic press, London, pp. 137-260.

17. Daling, P.S., Faksness, L.G., Hansen, A.B. and Stout, S.A. (2002) Improved and standardized methodology for oil fingerprinting. In Proceedings of the $25^{\text {th }}$ Arctic and Marine Oil Spill Program (AMOP) Technical Seminar, Environment Canada, Ottawa, Canada, pp. 429-454.

18. Wang, Z. and Fingas, M. (2003) Development of oil hydrocarbon fingerprinting and identification techniques. Mar. Pollut. Bull., 47: 423-452.

19. Risdon, G.C., Pollard, S.J.T., Brassington, K.J., McEwan, J.N., Paton, G.I., Semple, K.T. and Coulon, F. (2008) Development of an analytical procedure for weathered hydrocarbon contaminated soils within a UK risk-based framework. Anal. Chem. 80: 7090-7096.

20. Readman, J.W. (2010) Chemical analysis of hydrocarbons in petroleum oils and the assessment of environmental contamination. In Handbook of Hydrocarbon and Lipid Microbiology, Timmis, K.N. Ed. Springer-Verlag: Berlin Heidelberg, pp. 3576-582.

21. Askari, K. and Pollard, S.J.T. (2005) The UK approach for evaluating human health risks from petroleum hydrocarbons in soils, Science Report P5-080/TR3. Environment Agency, Rio House, Waterside Drive, Aztec West, Almondsbury, Bristol BS32 4UD, UK, pp. 1-22.

22. Barnes, B. (2009) Framework for the use of rapid measurement techniques (RMT) in the risk management of land contamination. Environment Agency, Rio House, Waterside Drive, Aztec West, Almondsbury, Bristol BS32 4UD, UK, pp. 1-90.

23. Graham, K.N. (1998) Evaluation of analytical methodologies for diesel fuel contaminants in soil. M.Sc. Thesis. University of Manitoba, Canada.

24. Malle, H. and Fowlie, P. (1998) A Canadian interlaboratory comparison for analysis of petroleum hydrocarbons in soil. In Proceedings of the second biennial international conference on chemical measurement and monitoring of the environment, EnviroAnalysis '98 Conference, Ottawa, Canada, May 11-14, pp. 321-322.

25. Malley, D.F., Hunter, K.N. and Barrie-Webster, G.R. (1999) Analysis of diesel fuel contamination in soils by near-infrared reflectance spectrometry and solid phase micro extraction-gas chromatography. Soil Sed. Contam., 8: 481-489.

26. Chakraborty, S., Weindorf, D.C., Morgan, C.L.S., Ge, Y., Galbraith, J.M., Li, B. and Kahlon, C.S. (2010) Rapid identification of oil-contaminated soils using visible nearinfrared diffuse reflectance spectroscopy. J. Environ. Qual., 39: 1378-1387.

27. Forrester, S., Janik, L. and McLaughlin, M. (2010) An infrared spectroscopic test for total petroleum hydrocarbon (TPH) contamination in soils. In Proceedings of the $19^{\text {th }}$ world congress of soil science, soil solutions for a changing world, Brisbane, Australia, August 1-6, pp. 13-16.

28. Bray, J.G., Viscarra Rossel, R.A., McBratney, A.B. (2010) Diagnostic screening of urban soil contaminants using diffuse reflectance spectroscopy. In Proximal Soil Sensing, Viscarra Rossel, R.A., McBratney, A.B. and Minasny, B. Eds. Springer-Verlag: Berlin Heidelberg, pp. 191-199.

29. Zhou, C., Wang, Q.E., Gao, S.S. and Zhuang, H.S. (2009) Determination of naphthalene by competitive fluorescence immunoassay. Environ. Monit. Assess. 154: 233-239.

30. Wei, M.Y., Wen, S.D., Yang, X.Q., Guo, L.H. (2009) Development of redox-labelled electrochemical immunoassay for polycyclic aromatic hydrocarbons with controlled surface modification and catalytic voltammetric detection. Biosens. Bioelectron., 24: 2909-2914.

31. Weisman, W. (1998) Analysis of petroleum hydrocarbons in environmental media. In Total Petroleum Hydrocarbon Criteria Working Group (TPHCWG) Series: vol. 1. Weisman, W. Ed. Amherst Scientific Publishers, Amherst, MA, pp. 1-98. 
32. Wang, Z. and Fingas M. (1995) Differentiation of the sources of spilled oil and monitoring of the oil weathering process using gas chromatography - mass spectroscopy. $J$. Chromatogr. A, 712: 321-343.

33. Brassington, K.J., Pollard, S.J.T. and Coulon, F. (2010) Weathered hydrocarbon wastes: A risk management primer. In Handbook of Hydrocarbon and Lipid Microbiology, Timmis K.N. Ed. Springer-Verlag: Berlin Heidelberg, pp. 2488-2499.

36. Whittaker, M., Pollard, S.J.T. and Fallick, T.E. (1995) Characterisation of refractory wastes at heavy oil-contaminated sites: A review of conventional and novel analytical methods. Environ. Technol., 16: 1009-1033.

37. Villalobos, M., Avila-Forcada, A.P. and Gutierrez-Ruiz, M.E. (2008) An improved gravimetric method to determine total petroleum hydrocarbons in contaminated soils. Water Air Soil Pollut., 194: 151-161.

38. Rhodes, I.A.L., Olvera, R.Z. and Leon, J.A. (1990) Determination of gasoline range total petroleum hydrocarbon and approximate boiling point distribution in soil by gas chromatography. In Hydrocarbon Contaminated Soils, Kostecki, P.T. and Calabrese, E.J. Eds. Lewis Publishers, MI, USA, pp. 273-290.

39. White, D.M. and Irvine, R.L. (1994) Analysis of bioremediation in organic soils, A joint meeting presentation; the Society of Chemical Industry and Royal Society of Chemistry, Sunbury on Thames, Middlesex, UK.

40. Douglas, G.S., McCaarthy, K.J., Dahlen, D.T., Seavey, J.A., Steinhauer, W.G., Prince, R.C. and Elmendorf, D.L. (1992) The use of hydrocarbon analyses for environmental assessment and remediation. J. Soil Contam., 1: 197-216.

41. Essington, M.E. (2004) Soil and water chemistry: An integrative approach, CRC Press Inc., Boca Raton, FL, USA.

42. Abu, G.O. and Atu, N.D. (2008) An investigation of oxygen limitation in microcosm models in the bioremediation of a typical Niger Delta soil ecosystem impacted with crude oil. J. Appl. Sci. Environ. Manage. 12: 13-22.

43. Adesodun, J.K. and Mbagwu, J.S.C. (2008) Biodegradation of waste-lubricating petroleum oil in a tropical alfisol as mediated by animal droppings. Bioresour. Technol., 99: 56595665.

44. Aske, N., Kallevik, H. and Sjoblom, J. (2001) Determination of saturate, aromatic, resin, and asphaltenic (SARA) components in crude oils by means of infrared and near-infrared spectroscopy. Energy Fuels, 15: 1304-1312.

45. Lambert, P. and Fingas, M., M. (2001) An evaluation of field total petroleum hydrocarbon (TPH) systems. J. Hazard. Mater., 83: 65-81.

46. Current, R.W. and Tilotta, D.C. (1997) Determination of total petroleum hydrocarbons in soil by on-line supercritical fluid extraction-infrared spectroscopy using a fibre-optic transmission cell and a simple filter spectrometer. J. Chromatogr. A, 785: 269-277.

47. Becker, R., Koch, M., Wachholz, S., Win, T. (2002) Quantification of total petrol hydrocarbons (TPH) in soil by IR-spectrometry and gas chromatography - conclusions from three proficiency testing rounds. Accredit. Qual. Assur., 7: 286-289.

48. Fan, C.Y., Krishnamurthy, S. and Chen, C.T. (1994) A critical review of analytical approaches for petroleum contaminated soil. In Analysis of soil contaminated with petroleum constituents, O'Shay, T.A. and Hoddinott, K.B. Eds. American Society for Testing and Materials ASTM STP 1221, Philadelphia, PA, pp. 61-74.

49. Sherma, J. (1972) Principles and techniques. In CRC Handbook of chromatography: general data and principles, vol. 2, Zweig, G. and Sherma, J. Eds. CRC Press Inc., Boca Raton, FL, 1-101. 
50. United States Environmental Protection Agency (USEPA) (1992) Test methods for evaluating solid waste $S W$ 846, $3^{\text {rd }}$ ed., Office of Solid Waste and Emergency Response, Washington, D.C.

51. United States Environmental Protection Agency (USEPA) (1996) Test Methods: polycyclic aromatic hydrocarbons - method 8270B, Environmental Monitoring and Support Laboratory, Cincinnati, $\mathrm{OH}$.

52. British Standard Institute (BSI) BS ISO 15009:2002 (2002) Soil quality - gas chromatographic determination of the content of volatile aromatic hydrocarbons, naphthalene and volatile halogenated hydrocarbons - purge-and-trap method with thermal desorption, 389 Chiswick High Road, London W4 4AL.

53. British Standard Institute (BSI) BS ISO 16703:2004 (2004) Soil quality - determination of content of hydrocarbon in the range C10 to C40 by gas chromatography, 389 Chiswick High Road, London W4 4AL.

54. Vallejo, B., Izquierdo, A., Blasco, R., Perez del Campo, P. and Luque de Castro, M.D. (2001) Bioremediation of an area contaminated by a fuel spill. J. Environ. Monit. 3: 274280.

55. Snape, I., Harvey, P.M., Ferguson, S.H., Rayner, J.L. and Revill, A. (2005) Investigation of evaporation and biodegradation of fuel spills in Antarctica I. a chemical approach using GC-FID. Chemosphere 61: 1485-1499.

56. Saari, E., Peramaki, P. and Jalonen, J. (2007) Effect of sample matrix on the determination of total petroleum hydrocarbons (TPH) in soil by gas chromatography-flame ionization detection. Microchem. J. 87: 113-118.

57. Frysinger, G., Gaines, R.B., Xu, L. and Reddy, C.M. (2003) Resolving the unresolved complex mixture in petroleum-contaminated sediments. Environ. Sci. Technol., 37: 16531662.

58. Eyvazi, M.J. and Zytner, R.G. (2009) A Correlation to estimate the bioventing degradation rate constant. Bioremed. J., 13: 141-153.

59. Creighton, K. and Richards, R. (1997) Field screening technique for total petroleum hydrocarbons in soils. Pract. Periodical Hazard. Toxic Radiat. / Waste Manage., 1: 78-83.

60. Krupcik, J., Oswald, P., Oktavec, D. and Armstrong, D.W. (2004) Calibration of GC-FID and IR-spectrometric methods for determination of high boiling petroleum hydrocarbons in environmental samples. Kluwer Acad. Publ., 153: 329-341.

61. Saari, E., Peramaki, P. and Jalonen, J. (2010) Evaluating the impact of GC operating settings on GC-FID performance for total petroleum hydrocarbon (TPH) determination. Microchem. J., 94: 73-78.

62. Masucci, J.A. and Caldwell, G.W. (2004) Techniques for gas chromatography/mass spectroscopy. In Modern Practice of Gas Chromatography, $4^{\text {th }}$ ed. Grob, R.L. and Barry E.F. Eds. John Willy and Sons Inc., Hoboken, NJ, pp. 339-401.

63. Poster, D.L., Schantz, M.M., Sander, L.C. and Wise, S.A. (2006) Analysis of polycyclic aromatic hydrocarbons (PAHs) in environmental samples: a critical review of gas chromatographic (GC) methods. Anal. Bioanal. Chem., 386: 859-881.

64. Peterson, G.S., Axler, R.P., Lodge, K.B., Schuldt, J.A. and Crane, J.L. (2002) Evaluation of a fluorometric screening method for predicting total PAH concentrations in contaminated sediments. Environ. Monit. Assess., 78: 111-129.

65. Lorenzi, D., Cave, M. and Dean, J.R. (2010) An investigation into the occurrence and distribution of polycyclic aromatic hydrocarbons in two soil size fractions at a former industrial site in NE England, UK using in situ PFE-GC-MS. Environ. Geochem. Health, 32: 553-565. 
66. Yang, Z., Yang, C., Wang, Z., Hollebone, B., Landriault, M. and Brown, C.E. (2011) Oil fingerprinting analysis using commercial solid phase extraction (SPE) cartridge and gas chromatography-mass spectrometry (GC-MS). Anal. Methods, 3: 628-635.

67. Zhang, Y., Zhu, Y.G., Houot, S., Qiao, M., Nunan, N. and Garnier, P. (2011) Remediation of polycyclic aromatic hydrocarbon $(\mathrm{PAH})$ contaminated soil through composting with fresh organic wastes. Environ. Sci. Pollut. Res. DOI 10.1007/s11356-011-0521-5.

68. Chuang, J.C., Van Emon, J.M., Chou, Y.L., Junod, N., Finegold, J.K., Wilson, N.K. (2003) Comparison of immunoassay and gas chromatography-mass spectrometry for measurement of polycyclic aromatic hydrocarbons in contaminated soil. Anal. Chim. Acta, 486: 31-39.

69. Kim, I.S., Ritchie, L., Setford, S., Taylor, J., Allen, M., Wilson, G., Heywood, R., Pahlavanpour, B. and Saini, S. (2001) Quantitative immunoassay for determining polycyclic aromatic hydrocarbons in electrical insulating oils. Anal. Chim. Acta, 450: 1325.

70. Zhang, Y.F., Ma, Y., Gao, Z.X. and Dai, S.G. (2010) Predicting the cross-reactivities of polycyclic aromatic hydrocarbons in ELISA by regression and CoMFA methods. Anal. Bioanal. Chem., 397: 1551-2557.

71. Aldstadt, J., St. Germain, R., Grundl, T. and Schweitzer, R. (2002) An in situ laser-induced fluorescence system for polycyclic aromatic hydrocarbon-contaminated sediments, United States Environmental Agency, Great Lakes National Program Office, Chicago, Illinois.

72. Quick Results On Site (QROS) (2012) Hydrocarbon analysis with $Q E D^{\circledR}$. Available at http://www.qros.co.uk/hydrocarbon_analysis.html [accessed 5 August 2012]

73. Greason, S. (2009) Field screening petroleum hydrocarbons using ultraviolet fluorescence technology, Sitelab Corporation, West Newbury, MA.

74. Bujewski, G. and Rutherford, B. (1997) The Rapid Optical Screening Tool (ROSTTM) laser-induced fluorescence (LIF) system for screening of petroleum hydrocarbons in subsurface soils, USEPA, Office of Research and Development, Washington DC.

75. Harris, C.M. (2003) Today's chemist at work, Am. Chem. Soc., 33-38.

76. Lyon, A., Keating, C.D., Fox, A.P., Baker, B.E., He, L., Nicewarner, S.R., Mulvaney, S.P. and Natan, M.J. (1998) Raman Spectroscopy. Anal. Chem., 70: 341R-361R.

77. Maddams, W.F. and Royaud, I.A.M. (1990) The characterization of polycyclic aromatic hydrocarbons by Raman spectroscopy. Spctrochim. Acta, 46A: 309-314.

78. Li, S. and Dai, L. (2012) Classification of gasoline brand and origin by Raman spectroscopy and a novel R-weighted LSSVM algorithm. Fuel, 96: 146-152.

79. Pfannkuche, J., Lubecki, L., Schmidt, H., Kowalewska, G. and Kronfeldt, H. (2012) The use of surface-enhanced Raman scattering (SERS) for detection of PAHs in the Golf of Gdansk (Baltic Sea). Mar. Pollut. Bull., 64: 614-626.

80. Jehlicka, J., Edwards, H.G.M., Villar, S.E.J. and Pokorny, J. (2005) Raman spectroscopic study of amorphous and crystalline hydrocarbons from soil, peats and lignite. Spctrochim. Acta, A 61: 2390-2398.

81. Brown, D.H. (2010) Comparison of spectra from a Raman IdentiCheck versus an Ahura® TruScan ${ }^{\circledR}$ Raman Spectrometer. Field Application Report - Raman Spectroscopy, PerkinElmer Inc., Shelton, CT, USA

82. Osborne, B.G., Fearn, T. and Hindle, P.H. (1993) Practical NIR spectroscopy - with applications in food and beverage analysis, $2^{\text {nd }} e d$. Longman Group UK Limited, Longman House Burnt Mill, Harlow Essex CM20 2JE, England.

83. Adamchuk, V.I., Hummel, J.W., Morgan, M.T. and Upadhyaya, S.K. (2004) On-the-go soil sensors for precision agriculture. Comput. Electron. Agric., 44: 71-91.

84. Cloutis, E.A. (1989) Spectral reflectance properties of hydrocarbons: remote-sensing implications. Sci. 245: 87-89. 
85. Workman, J.J. (1999) Review of process and non-invasive near-infrared and infrared spectroscopy: 1993-1999. Appl. Spectrosc. Rev., 34: 1-89.

86. Schwartz, G., Eshel, G. and Ben-Dor, E. (2011) Reflectance spectroscopy as a tool for monitoring contaminated soils. In Soil Contam., Pascucci, S. Ed. InTech., 67-90.

87. Schneider, I., Nau, G., King, T.V.V. and Aggarwal, I. (1995) Fibre-optic near-infrared reflectance sensor for detection of organics in soils. IEEE Photonics Technol. Letters, 7: 87-89.

88. Stallard, B.R., Garcia, M.J. and Kaushik, S. (1996) Near-IR reflectance spectroscopy for the determination of motor oil contamination in sandy loam. Appl. Spectrosc., 50: 334338.

89. Zwanziger, Z. and Heidrun, F. (1998) Near infrared spectroscopy of fuel contaminated sand and soil. I. Preliminary results and calibration study. J. Near Infrared Spectrosc. 6: 189-197.

90. Chakraborthy, S., Weindorf, D.C., Zhu, Li, Y., B., Morgan, C.L.S., Ge, Y. and Gulbraith, J. (2012) Spectral reflectance variability from soil physicochemical properties in oil contaminated soils. Geoderma, 177-178: 80-89.

91. Schwartz, G., Ben-Dor, E. and Eshel, G. (2012) Quantitative analysis of total petroleum hydrocarbons in soils: comparison between reflectance spectroscopy and solvent extraction by 3 certified laboratories. Appl. Environ. Soil Sci., 2012: 1-11.

92. Okparanma, R.N. and Mouazen, A.M. (2012) Analyses of the influence of oil concentration, clay and moisture contents on diffuse reflectance spectra of dieselcontaminated soils. Sens. Actuators B: Chem., Article in Review.

93. Stenberg, B. (2010) Effects of soil sample pre-treatments and standardized rewetting as interacted with sand classes on Vis-NIR predictions of clay and soil organic carbon. Geoderma, 158: 15-22.

94. Billets, S. (2001) Innovative technology verification report - field measurement technologies for total petroleum hydrocarbons in soil. United States Environmental Protection Agency (USEPA), Office of Research and Development, Washington DC.

95. Nording, M., Frech, K., Persson, Y., Forsman, M. and Haglund, P. (2006) On the semiquantification of polycyclic aromatic hydrocarbons in contaminated soil by an enzymelinked immunosorbent assay kit. Anal. Chim. Acta, 555: 107-113.

96. Forrester, S., Janik, L. and McLaughlin, M. (2010) In-situ determination of total petroleum hydrocarbon (TPH) contamination: a quick infrared spectroscopic test for TPH at contaminated sites. Poster presented at the $19^{\text {th }}$ world congress of soil science, soil solutions for a changing world, Brisbane, Australia, August 1-6, pp. 1.

97. GE Security Inc. (2006) Raman spectroscopy: the science behind the technology, GE Homeland Protection Inc. Available at http://www.gesecurity.com [accessed 5 September 2012].

98. Naes, T., Isaksson, T., Fearn, T. and Davies, T. (2002) A user friendly guide to multivariate calibration and classification, NIR Publications, Chichester, UK.

99. Mouazen, A.M., Kuang, B., De Baerdemaeker, J. and Ramon, H. (2010) Comparison among principal component, partial least squares and back propagation neural network analyses for accuracy of measurement of selected soil properties with visible and near infrared spectroscopy. Geoderma, 158: 23-31.

100. Mouazen, A.M., De Baerdemaeker, J., Ramon, H. (2006) Effect of wavelength range on the measurement accuracy of some selected soil constituents using visual-near infrared spectroscopy. J. Near Infrared Spectrosc., 14: 189-199.

101. Puppels, G.J., Colier, W., Olminkhof, J.H.F., Otto, C., de Mul, F.F.M. and Greve, J. (1991) Description and performance of a highly sensitive confocal Raman micro spectrometer. $J$. Raman Spectrosc., 22: 217-225. 
102. Lohmannsroben, H.G. and Roch, T. (2000) In situ laser-induced fluorescence (LIF) analysis of petroleum product-contaminated soil samples. J. Environ. Monit., 2: 17-22.

103. Sitelab Corporation (2010) Polycyclic aromatic hydrocarbon application using Sitelab UVF-3100D, Sitelab Corporation, 86 Coffin Street, West Newbury, MA, USA.

104. Schultze, R.H. and Lewitzka, F. (2005) On-site and in-situ analysis of contaminated soils using laser induced fluorescence spectroscopy. In Remote Sensing for Environmental Monitoring, GIS Applications, and Geology V, Ehlers, M. and Michel, U. Eds. Proceedings of SPIE, 5983: pp. 1-10. 


\section{List of captions}

Table 1: Summary of selected spectroscopic and non-spectroscopic techniques for petroleum hydrocarbon measurement (modified with permission from Reference (31))

Table 2: Capital cost of selected total petroleum and polycyclic aromatic hydrocarbon analytical devices (as of 2012; from the below companies ${ }^{\dagger}$ )

Table 3: Characteristics of selected petroleum hydrocarbon measurement techniques (modified with permission from Reference (31))

Table 4: Measurement accuracy of selected measurement techniques for petroleum hydrocarbons in contaminated soils

Table 5: Attributes of general applicability for selected analytical methods for total petroleum and polycyclic aromatic hydrocarbons in soil 
1 3 4 5

Table 1: Summary of selected spectroscopic and non-spectroscopic techniques for petroleum hydrocarbon measurement (modified with permission from Reference (31))

\begin{tabular}{lll}
\hline Measurement technique & Detection device & Measured Target \\
\hline Gas Chromatography & Flame ionisation detector (FID) & TPH \\
& Mass spectrometry (MS) & TPH, PAH and CSB \\
Infrared Spectroscopy & IR spectrometer & TPH and PAH \\
General Gravimetry & Gravimetric balance & TPH \\
Immunoassay & ELISA kits & TPH and PAH \\
& ECIA kits & TPH and PAH \\
Raman Spectroscopy & CCD detector & TPH and PAH \\
Fluorescence Spectroscopy & Polychromator / CCD camera & TPH and PAH \\
& SIT camera & TPH and PAH \\
Visible and Near-infrared & High intensity probe / Mug lamp & TPH and PAH \\
Spectroscopy & & \\
\hline
\end{tabular}

CCD, Charge-coupled device

CSB, Compound specific biomarkers

ECIA, Electrochemical immunoassay

ELISA, Enzyme-linked immunosorbent assay

PAH, Polycyclic aromatic hydrocarbon

SIT - Silicon intensified target

TPH, Total petroleum hydrocarbon 
Table 2: Capital cost of selected total petroleum and polycyclic aromatic hydrocarbon analytical devices (as of 2012; from the below companies ${ }^{\dagger}$ )

\begin{tabular}{llll}
\hline Technique & Make & Model & Price (\$) (approx.) \\
\hline Gas Chromatography & Agilent Technologies & 6890 N GC/FID & 28,000 (used) \\
& Agilent Technologies & GC/MS 6890/5975 & 39,900 (used) \\
& Thermo Fisher & LTQ Orbitrap & 362,486 \\
& Agilent Technologies & 3000 Micro GC 1-, 2-channel systems (portable) & $17,000-50,000$ \\
& zNose ${ }^{\text {TM }}$ & Model 4200 (bench-top) & $21,000-26,000$ \\
& Bruker Instruments & EM 640 (portable) & $149,530-175,375$ \\
Shimadzu & IR400 & 3,528 \\
& Thermo Fisher & 370 DTGS & 7,055 \\
& Thermo Scientific & Nicolet 6700 FTIR & 14,900 (used) \\
& Agilent Technologies & 4100 ExoScan FTIR (Diffuse Reflectance Head) & 43,497 \\
& Agilent Technologies & 4100 ExoScan FTIR (Universal System) & 61,301
\end{tabular}

${ }^{\dagger}$ LabX, Canada; Analytik Ltd., UK; O. I. Analytical Corp., USA; StellarNet Inc., USA 
Table 2: Capital cost of selected total petroleum and polycyclic aromatic hydrocarbon analytical devices (as of 2012; from the below companies ${ }^{\dagger}$ )

\begin{tabular}{llll}
\hline Technique & Make & Model & Price (\$) (approx.) \\
\hline Visible and Near- & Analytical Spectral Devices & Quality-SpecPro $^{\circledR}$ & 48,563 \\
infrared Spectroscopy & & LabSpec $^{\circledR} 2500$ & 56,688 \\
& & LabSpec $^{\circledR} 5000$ & 61,078 \\
Fluorescence & Hitachi & F-4010 & 2,500 \\
Spectroscopy & Tecan & Spectra Fluor & 8,200 \\
& Perkin Elmer & LS5B & 4,500 \\
Raman Spectroscopy & - & Raman-HR-TEC-IG & 17,777 \\
& - & Raman-HR-TEC & 5,295 \\
& - & Raman-HR & 4,000
\end{tabular}

${ }^{\dagger}$ LabX, Canada; Analytik Ltd., UK; O. I. Analytical Corp., USA; StellarNet Inc., USA 
Table 3: Characteristics of selected petroleum hydrocarbon measurement techniques (modified with permission from Reference (31))

\begin{tabular}{|c|c|c|c|c|c|c|}
\hline Technique & $\begin{array}{l}\text { Application } \\
\text { method }\end{array}$ & $\begin{array}{l}\text { Approx. LDL } \\
(\mathrm{mg} / \mathrm{kg})^{\mathrm{a}}\end{array}$ & $\begin{array}{l}\text { Estimated analysis run } \\
\text { time (minutes) }\end{array}$ & Sampling type & Strength & Limitations \\
\hline GC-Based & $\begin{array}{l}\text { Laboratory } \\
\text { and field }\end{array}$ & 10 & $\begin{array}{l}45-2880^{\mathrm{b}, \mathrm{c}} \\
\text { (Excluding extraction } \\
\text { time, lab-based GC cycle } \\
\text { time may be } 40 \text { minutes } \\
\text { while some portable } \\
\text { devices take }<10 \text { seconds) }\end{array}$ & $\begin{array}{l}\text { Purge \& trap, } \\
\text { Head-space, } \\
\text { Solvent } \\
\text { extraction }\end{array}$ & $\begin{array}{l}\text { Selectivity and high } \\
\text { sensitivity; oil source } \\
\text { identification; specific } \\
\text { (MSD); quantitative } \\
\text { and qualitative } \\
\text { applications, portable, } \\
\text { rapid }\end{array}$ & $\begin{array}{l}\text { Laboratory-based GCs are } \\
\text { not for compounds < C6; } \\
\text { Non-specific (FID); specific } \\
\text { (MSD); Expensive (capital } \\
\text { equipment and analytical } \\
\text { costs); Problem of co- } \\
\text { elution; expensive; requires } \\
\text { expertise; produces COPC }\end{array}$ \\
\hline
\end{tabular}






\section{Page 41 of 58}

Applied Spectroscopy Reviews

Table 3: Characteristics of selected petroleum hydrocarbon measurement techniques (modified with permission from Reference (31)) Continued

\begin{tabular}{|c|c|c|c|c|c|c|}
\hline Technique & $\begin{array}{l}\text { Application } \\
\text { method }\end{array}$ & $\begin{array}{l}\text { Approx. LDL } \\
(\mathrm{mg} / \mathrm{kg})^{\mathrm{a}}\end{array}$ & $\begin{array}{l}\text { Estimated analysis run } \\
\text { time (minutes) }\end{array}$ & Sampling type & Strength & Limitations \\
\hline IR-Based & $\begin{array}{l}\text { Laboratory } \\
\text { and field }\end{array}$ & $6.32^{j}-15.2^{d}$ & $\begin{array}{l}1^{\mathrm{m}} \text { (Excluding sample } \\
\text { extraction time for lab- } \\
\text { based bench-top device) } \\
0.3^{\mathrm{m}} \text { (No sample } \\
\text { extraction required for the } \\
\text { portable device) }\end{array}$ & $\begin{array}{l}\text { Solvent } \\
\text { extraction (lab- } \\
\text { based)/ Diffuse } \\
\text { reflectance } \\
\text { (portable type) }\end{array}$ & $\begin{array}{l}\text { Quick, simple and } \\
\text { inexpensive, portable }\end{array}$ & $\begin{array}{l}\text { Non-specific; low } \\
\text { sensitivity; analytical losses; } \\
\text { poor extraction efficiency; } \\
\text { quantitative application } \\
\text { only; produces COPC }\end{array}$ \\
\hline Gravimetric & Laboratory & 50 & - & $\begin{array}{l}\text { Solvent } \\
\text { extraction }\end{array}$ & $\begin{array}{l}\text { Quick, simple and } \\
\text { inexpensive }\end{array}$ & $\begin{array}{l}\text { Non-specific; low } \\
\text { sensitivity; analytical losses; } \\
\text { poor extraction efficiency; } \\
\text { quantitative application } \\
\text { only; produces COPC }\end{array}$ \\
\hline
\end{tabular}

\footnotetext{
${ }^{\mathrm{a}}$ In soil

${ }^{\mathrm{d}}$ Reference (73)

${ }^{j}$ Reference (94)

${ }^{\mathrm{m}}$ Reference (96)
} 
Table 3: Characteristics of selected petroleum hydrocarbon measurement techniques (modified with permission from Reference (31)) Continued

\begin{tabular}{|c|c|c|c|c|c|c|}
\hline Technique & $\begin{array}{l}\text { Application } \\
\text { method }\end{array}$ & $\begin{array}{l}\text { Approx. LDL } \\
(\mathrm{mg} / \mathrm{kg})^{\mathrm{a}}\end{array}$ & $\begin{array}{l}\text { Estimated analysis run } \\
\text { time (minutes) }\end{array}$ & Sampling type & Strength & Limitations \\
\hline Immunoassay & Field & $\begin{array}{l}\text { 10-500 (under } \\
\text { laboratory } \\
\text { conditions, } 0.1 \\
\text { has been } \\
\text { achieved with } \\
\text { trained staff) }\end{array}$ & $1.5-3^{\mathrm{e}}$ & Optical density & $\begin{array}{l}\text { Quick, simple, } \\
\text { inexpensive and } \\
\text { portable; increasingly } \\
\text { reasonable accuracy }\end{array}$ & $\begin{array}{l}\text { Non-specific; low } \\
\text { sensitivity; only measures } \\
\text { aromatics; quantitative } \\
\text { application; screening only, } \\
\text { cross-reactivity }\end{array}$ \\
\hline
\end{tabular}

\footnotetext{
${ }^{\mathrm{a}}$ In soil

${ }^{\mathrm{e}}$ Dexsil, USA

${ }^{1}$ Reference (68)

LDL, Laboratory detection limit
} 
Table 3: Characteristics of selected petroleum hydrocarbon measurement techniques (modified with permission from Reference (31)) Continued

\begin{tabular}{|c|c|c|c|c|c|c|}
\hline Technique & $\begin{array}{l}\text { Application } \\
\text { method }\end{array}$ & $\begin{array}{l}\text { Approx. LDL } \\
(\mathrm{mg} / \mathrm{kg})^{\mathrm{a}}\end{array}$ & $\begin{array}{l}\text { Estimated analysis run } \\
\text { time (minutes) }\end{array}$ & Sampling type & Strength & Limitations \\
\hline NIR-Based & Field & $1.0^{\mathrm{f}}$ & $\begin{array}{l}0.6^{\mathrm{g}}-<2^{\mathrm{h}} \\
\text { (depends on the } \\
\text { number of scans } \\
\text { per sample) }\end{array}$ & $\begin{array}{l}\text { Diffuse } \\
\text { reflectance/ } \\
\text { transmittance } \\
\text { spectra }\end{array}$ & $\begin{array}{l}\text { Rapid, simple, inexpensive, } \\
\text { portable, zero-solvent } \\
\text { extraction, non-invasive, } \\
\text { little or no sample } \\
\text { preparation }\end{array}$ & $\begin{array}{l}\text { Non-specific, matrix effect } \\
\text { (water, soil \& nature of oil), } \\
\text { overlapping spectra, long } \\
\text { pathlength, indirect } \\
\text { correlation, qualitative } \\
\text { applications, high-level } \\
\text { chemometrics }\end{array}$ \\
\hline
\end{tabular}

${ }^{\mathrm{f}}$ Reference (25)

${ }^{\mathrm{g}}$ Reference (23)

${ }^{\mathrm{h}}$ Reference (25)

LDL, Laboratory detection limit 
Table 3: Characteristics of selected petroleum hydrocarbon measurement techniques (modified with permission from Reference (31)) Continued

\begin{tabular}{|c|c|c|c|c|c|c|}
\hline Technique & $\begin{array}{l}\text { Application } \\
\text { method }\end{array}$ & $\begin{array}{l}\text { Approx. LDL } \\
(\mathrm{mg} / \mathrm{kg})^{\mathrm{a}}\end{array}$ & $\begin{array}{l}\text { Estimated analysis run } \\
\text { time (minutes) }\end{array}$ & Sampling type & Strength & Limitations \\
\hline Fluorescence- & Laboratory & $0.05^{\mathrm{d}}$ & $2.6^{\mathrm{d}}$ & Emission & Rapid, portable, specific, & Qualitative applications \\
\hline Based & and field & & $\begin{array}{l}\text { (Excludes extraction } \\
\text { time) }\end{array}$ & spectra & $\begin{array}{l}\text { inexpensive, quantitative } \\
\& \text { qualitative applications }\end{array}$ & $\begin{array}{l}\text { only, sensitive to non- } \\
\text { hydrocarbons, sensitivity is } \\
\text { affected by soil matrix, prior } \\
\text { sample extraction is } \\
\text { required }\end{array}$ \\
\hline Raman & Laboratory & - & $0.1^{\mathrm{i}}-<3^{\mathrm{k}}$ & Emission & Rapid, portable, non- & Laser alteration of samples, \\
\hline Spectroscopy & and field & & & spectra & $\begin{array}{l}\text { invasive, inexpensive, } \\
\text { quantitative \& qualitative } \\
\text { application, specific }\end{array}$ & fluorescence contamination \\
\hline
\end{tabular}

\footnotetext{
${ }^{\mathrm{a}}$ In soil

${ }^{\mathrm{d}}$ Reference (73)

${ }^{\mathrm{i}}$ DeltaNu, Inc., USA

${ }^{\mathrm{k}}$ Reference (101)

LDL, Laboratory detection limit
} 
Table 4: Measurement accuracy of selected measurement techniques for petroleum hydrocarbons in contaminated soils

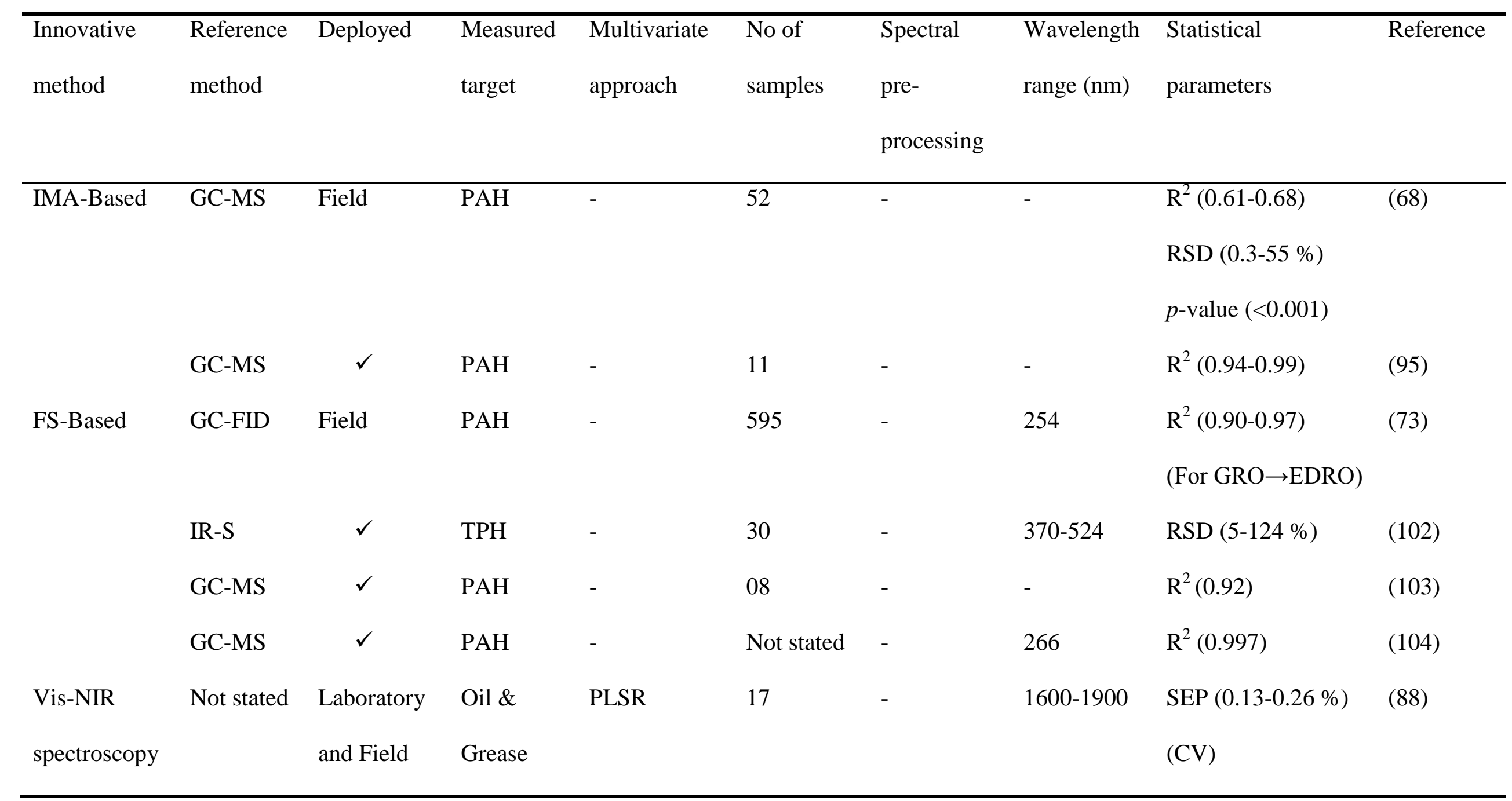

AVG - Average

45

URL: http://mc.manuscriptcentral.com/spectroscopy Email: jsneddon@mcneese.edu 
$\mathrm{CV}$ - Cross validation

EDRO - Extended diesel range organics

GRO - Gasoline range organics

IR-S - Infrared spectrometer

PAC - Polynuclear aromatic compound

PAH - Polycyclic aromatic hydrocarbon

PLSR - Partial least squares regression

RSD - Relative standard deviation (SD/AVG)

SD - Standard deviation

SEP - Standard error of prediction (in $\mathrm{mg} / \mathrm{kg}$ )

Vis-NIR - Visible and Near-infrared 
Table 4: Measurement accuracy of selected measurement techniques for petroleum hydrocarbons in contaminated soils (continued)

\begin{tabular}{|c|c|c|c|c|c|c|c|c|c|}
\hline $\begin{array}{l}\text { Innovative } \\
\text { method }\end{array}$ & $\begin{array}{l}\text { Reference } \\
\text { method }\end{array}$ & Deployed & $\begin{array}{l}\text { Measured } \\
\text { target }\end{array}$ & $\begin{array}{l}\text { Multivariate } \\
\text { approach }\end{array}$ & $\begin{array}{l}\text { No of } \\
\text { samples }\end{array}$ & $\begin{array}{l}\text { Spectral pre- } \\
\text { processing }\end{array}$ & $\begin{array}{l}\text { Wavelength } \\
\text { range }(\mathrm{nm})\end{array}$ & Statistical parameter & Reference \\
\hline $\begin{array}{l}\text { Vis-NIR } \\
\text { spectroscopy }\end{array}$ & Not stated & $\begin{array}{l}\text { Laboratory } \\
\text { and Field }\end{array}$ & $\begin{array}{l}\text { Oil \& } \\
\text { Grease }\end{array}$ & PLSR & $>25$ & $\begin{array}{l}\text { Apparent } \\
\text { absorbance, } \\
\text { Kubelka-Munk } \\
\text { transformation, } \\
\text { Saunderson } \\
\text { correction, } \\
\text { Mean value } \\
\text { centring, MSC }\end{array}$ & $800-2700$ & $\begin{array}{l}\mathrm{R}_{\mathrm{cv}}^{2}(0.968-0.998) \\
\mathrm{SEP}(0.116-1.04)(\mathrm{CV}) \\
\text { Bias }(-0.001-0.586) \\
\text { RMSD }(0.106-0.948) \\
(\mathrm{CV}) \\
\text { (Note: Diesel data only) }\end{array}$ & (89) \\
\hline & GC-FID & $\checkmark$ & TPH & $\begin{array}{l}\text { Stepwise } \\
\text { MLR }\end{array}$ & 26 & $\begin{array}{l}\text { Wavelength } \\
\text { average, First } \\
\text { derivative, \& } \\
\text { Smoothing } \\
\text { splines }\end{array}$ & $1100-2498$ & $\begin{array}{l}\mathrm{R}_{\mathrm{p}}^{2}(0.68-0.72) \\
\operatorname{SEP}(0.84-1.00) \\
\operatorname{RPD}(1.76-1.82)\end{array}$ & $(25)$ \\
\hline
\end{tabular}


BRT - Boosted regression tree

FTIR - Fourier transform infrared spectroscopy

MLR - Multiple linear regressions

MSC - Multiplicative scatter correction

PLSR - Partial least squares regression

$\mathrm{R}^{2}$ - Correlation coefficient $(\mathrm{CV}$, cross validation; $\mathrm{P}$, prediction)

RMSE - Root-mean-error (CV, cross validation; $\mathrm{P}$, prediction, in $\mathrm{mg} / \mathrm{kg}$ )

RPD - Residual prediction deviation $=(\mathrm{SD} / \mathrm{RMSEP})$

$\mathrm{SEP}$ - Standard error of prediction (in $\mathrm{mg} / \mathrm{kg}$ )

TPH - Total petroleum hydrocarbon

Vis-NIR - Visible and Near-infrared 


\section{Page 49 of 58}

\section{Applied Spectroscopy Reviews}

Table 4: Measurement accuracy of selected measurement techniques for petroleum hydrocarbons in contaminated soils (continued)

\begin{tabular}{|c|c|c|c|c|c|c|c|c|c|}
\hline $\begin{array}{l}\text { Innovative } \\
\text { method }\end{array}$ & $\begin{array}{l}\text { Reference } \\
\text { method }\end{array}$ & Deployed & $\begin{array}{l}\text { Measured } \\
\text { target }\end{array}$ & $\begin{array}{l}\text { Multivariate } \\
\text { approach }\end{array}$ & $\begin{array}{l}\text { No of } \\
\text { samples }\end{array}$ & $\begin{array}{l}\text { Spectral pre- } \\
\text { processing }\end{array}$ & $\begin{array}{l}\text { Wavelength } \\
\text { range }(\mathrm{nm})\end{array}$ & Statistical parameter & Reference \\
\hline $\begin{array}{l}\text { Vis-NIR } \\
\text { spectroscopy }\end{array}$ & Gravimetric & $\begin{array}{l}\text { Laboratory } \\
\text { and Field }\end{array}$ & TPH & PLSR, BRT & 46 & $\begin{array}{l}\text { Parabolic } \\
\text { splice, } \\
\text { Wavelength } \\
\text { average, First } \\
\text { derivative, } \\
\text { Second } \\
\text { derivative, } \\
\text { smoothing } \\
\text { splines }\end{array}$ & $350-2500$ & $\begin{array}{l}\mathrm{R}_{\mathrm{cv}}^{2}(0.64-0.85) \\
\mathrm{R}_{\mathrm{p}}^{2}(0.42-0.64) \\
\operatorname{RMSEP}(0.335-0.589) \\
\operatorname{RMSECV}(0.303-0.436) \\
\mathrm{RPD}(1.35-1.94) \\
\text { Bias }(-0.07-0.14)\end{array}$ & (26) \\
\hline \multicolumn{10}{|c|}{ AVG-Average } \\
\hline \multicolumn{10}{|c|}{ FPR - False positive rate } \\
\hline & $\mathrm{R}$ - Multiple & near regressi & is & & 49 & & & & \\
\hline & & URL & $: / / m c . m a$ & criptcentral. & n/spectro & copy Email: j: & ddon@mcnees & edu & \\
\hline
\end{tabular}




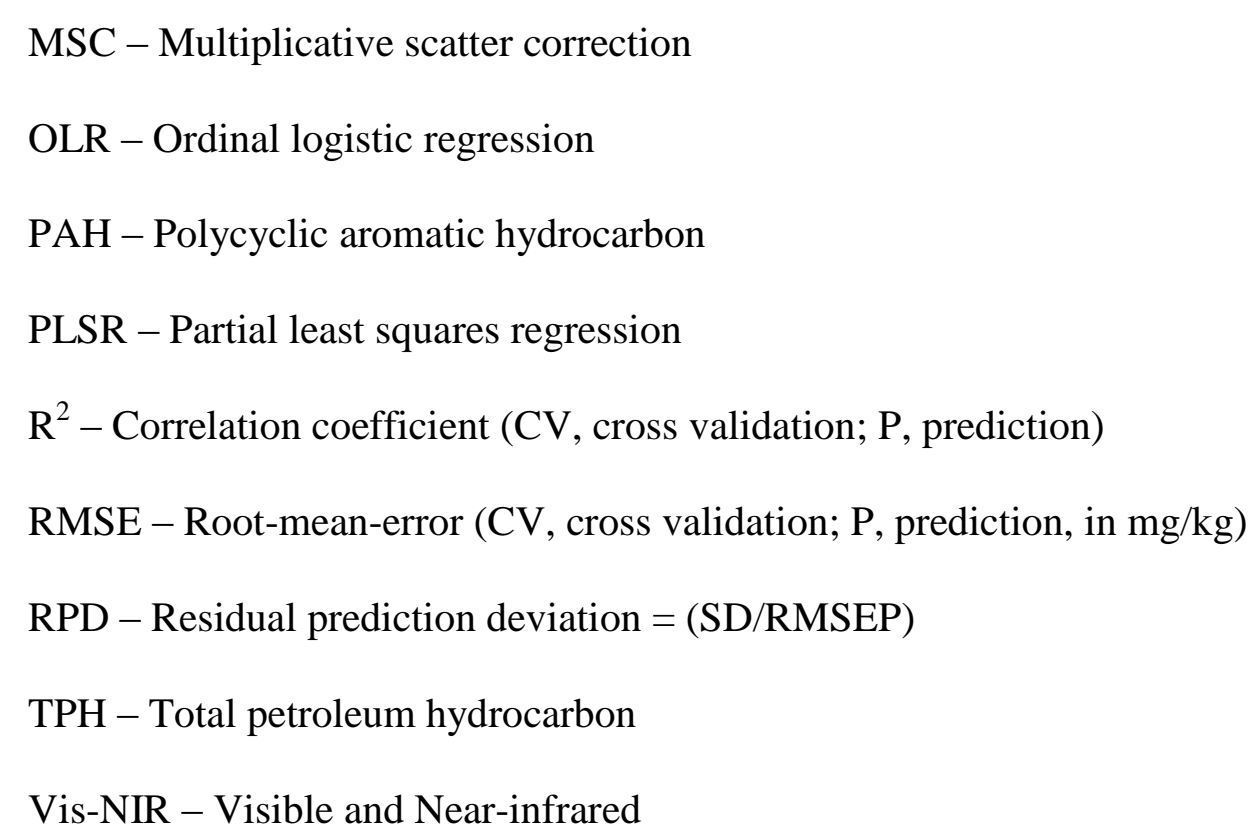


Table 4: Measurement accuracy of selected measurement techniques for petroleum hydrocarbons in contaminated soils (continued)

\begin{tabular}{|c|c|c|c|c|c|c|c|c|c|}
\hline $\begin{array}{l}\text { Innovative } \\
\text { method }\end{array}$ & $\begin{array}{l}\text { Reference } \\
\text { method }\end{array}$ & Deployed & $\begin{array}{l}\text { Measured } \\
\text { target }\end{array}$ & $\begin{array}{l}\text { Multivariate } \\
\text { approach }\end{array}$ & $\begin{array}{l}\text { No of } \\
\text { samples }\end{array}$ & $\begin{array}{l}\text { Spectral pre- } \\
\text { processing }\end{array}$ & $\begin{array}{l}\text { Wavelength } \\
\text { range }(\mathrm{nm})\end{array}$ & Statistical parameter & Reference \\
\hline \multirow[t]{4}{*}{$\begin{array}{l}\text { Vis-NIR } \\
\text { spectroscopy }\end{array}$} & $\overline{\text { FTIR }}$ & $\checkmark$ & TPH & $\overline{P L S R}$ & 172 & Not reported & $400-2500$ & $\begin{array}{l}\mathrm{R}_{\mathrm{cv}}^{2}(0.81) \\
\mathrm{RMSECV}(4500-8000 \\
\mathrm{mg} / \mathrm{kg})\end{array}$ & (27) \\
\hline & 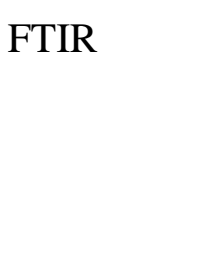 & 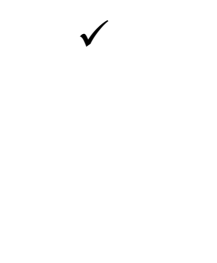 & PAH & OLR & 65 & Not reported & $350-2500$ & $\begin{array}{l}\text { Accuracy }(65.85-90.25 \%) \\
\text { FPR }(0.57-0.91) \\
\text { FNR }(0.03-0.13)\end{array}$ & (28) \\
\hline & Not stated & $\begin{array}{l}\text { Laboratory } \\
\text { and Field }\end{array}$ & TPH & $\begin{array}{l}\text { PLSR, } \\
\text { MLR, } \\
\text { Penalised } \\
\text { Spline }\end{array}$ & 68 & $\begin{array}{l}\text { First derivative, } \\
\text { Discrete wavelet } \\
\text { transform }\end{array}$ & $350-2500$ & $\begin{array}{l}\mathrm{R}_{\mathrm{cv}}^{2}(0.84-0.98) \\
\mathrm{RMSECV}(3010-4791) \\
\operatorname{RPD}(2.50-3.97)\end{array}$ & (90) \\
\hline & $\begin{array}{l}\text { R-Multipl } \\
\text { H - Polycyc } \\
\text { R - Partial }\end{array}$ & $\begin{array}{l}\text { linear regres } \\
\text { ic aromatic hy } \\
\text { east squares } r\end{array}$ & $\begin{array}{l}\text { ons } \\
\text { grocarbon } \\
\text { gression }\end{array}$ & uscriptcentra & .com/spe & roscopy Email: js & on@mcnees & du & \\
\hline
\end{tabular}


$\mathrm{R}^{2}$ - Correlation coefficient $(\mathrm{CV}$, cross validation; $\mathrm{P}$, prediction)

RMSE - Root-mean-error (CV, cross validation; $\mathrm{P}$, prediction, in $\mathrm{mg} / \mathrm{kg}$ )

RPD - Residual prediction deviation $=(\mathrm{SD} / \mathrm{RMSEP})$

TPH - Total petroleum hydrocarbon

Vis-NIR - Visible and Near-infrared 


\section{Page 53 of 58}

\section{Applied Spectroscopy Reviews}

Table 4: Measurement accuracy of selected measurement techniques for petroleum hydrocarbons in contaminated soils (continued)

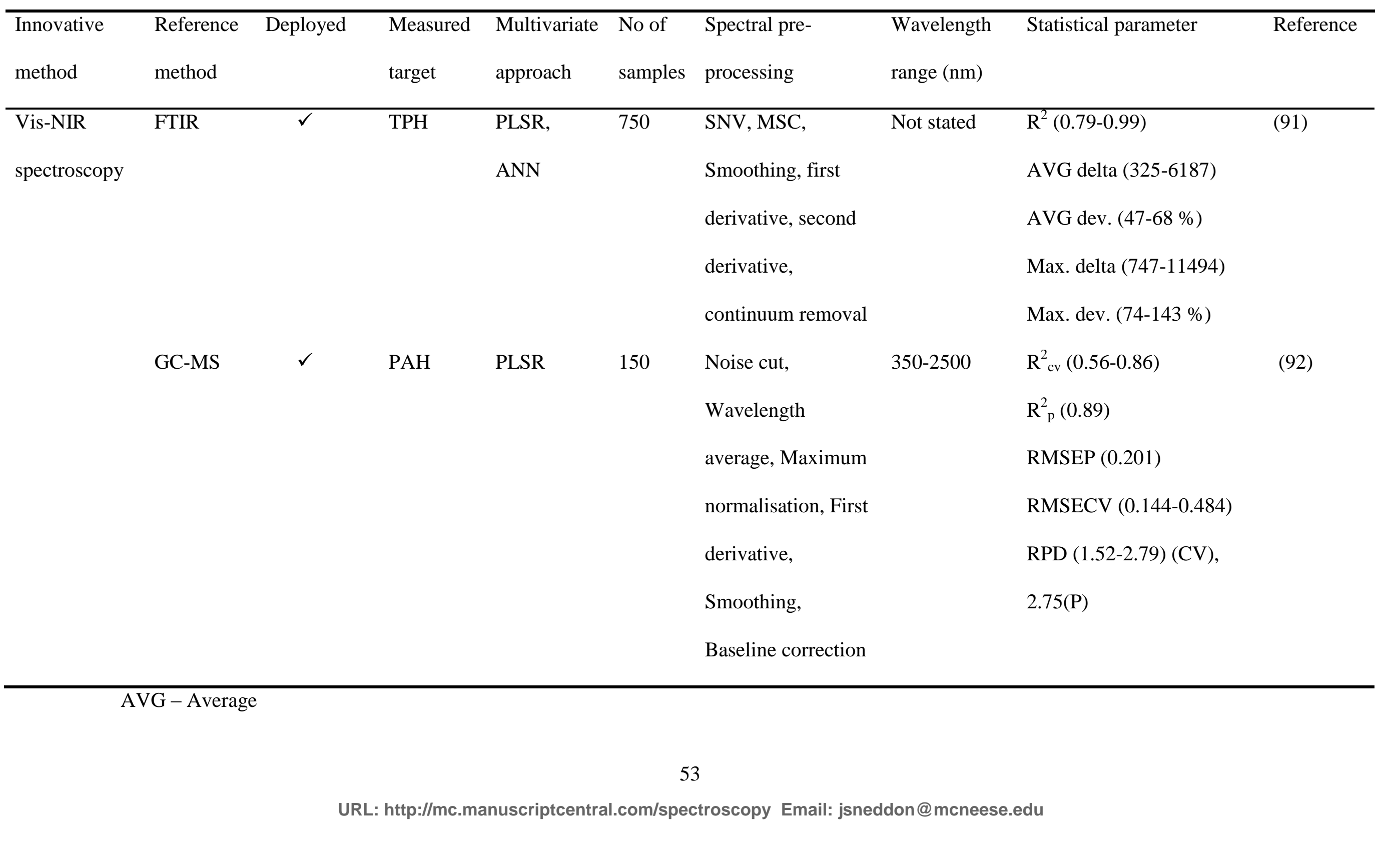


MLR - Multiple linear regressions

MSC - Multiplicative scatter correction

PAH - Polycyclic aromatic hydrocarbon

PLSR - Partial least squares regression

$\mathrm{R}^{2}$ - Correlation coefficient ( $\mathrm{CV}$, cross validation; $\mathrm{P}$, prediction)

RMSE - Root-mean-error (CV, cross validation; $\mathrm{P}$, prediction, in $\mathrm{mg} / \mathrm{kg}$ )

RPD - Residual prediction deviation $=(\mathrm{SD} / \mathrm{RMSEP})$

SNV - Standard normal variate

TPH - Total petroleum hydrocarbon

Vis-NIR - Visible and Near-infrared 
Table 5: Attributes of general applicability for selected analytical methods for total petroleum and polycyclic aromatic hydrocarbons in soil

\begin{tabular}{|c|c|c|c|c|c|c|}
\hline & $\begin{array}{l}\text { Economic } \\
\text { considerations }^{\dagger}\end{array}$ & $\begin{array}{l}\text { Operational } \\
\text { time }\end{array}$ & $\begin{array}{l}\text { Occupational } \\
\text { Health \& Safety }\end{array}$ & Portability & Accuracy ${ }^{\dagger \dagger}$ & $\begin{array}{l}\text { Overall score } \\
(\%)\end{array}$ \\
\hline Gas Chromatography & $x x$ & $x x$ & $x$ & $x \times x x$ & $x \times x x$ & 65 \\
\hline Infrared Spectroscopy & $x \times x$ & $x \times x$ & $x x$ & $x \times x x$ & $x \times x \times$ & 80 \\
\hline Gravimetric & $x \times x x$ & $x x$ & $x$ & $x$ & $x \times x \times$ & 60 \\
\hline Immunoassay & $x \times x \times$ & $x \times$ & $x x$ & $x \times x \times$ & $x \times x$ & 75 \\
\hline Fluorescence Spectroscopy & $x \times x x$ & $x \times x$ & $x x$ & $x \times x \times$ & $x \times x \times$ & 85 \\
\hline Raman Spectroscopy & $x \times x \times$ & $x \times x \times$ & $x \times x$ & $x \times x \times$ & - & Incomplete \\
\hline Vis-NIR Spectroscopy & $x \times x$ & $x \times x \times$ & $x \times x$ & $x \times x \times$ & $x \times$ & 80 \\
\hline \multicolumn{7}{|l|}{$\times$ Poor } \\
\hline \multicolumn{7}{|l|}{$x \times$ Fair } \\
\hline \multicolumn{7}{|l|}{$x \times x$ Good } \\
\hline$x \times x \times$ Excellent & & & & & & \\
\hline
\end{tabular}


$\dagger$ Note: the accuracy of the standard methods is assumed excellent since they are used as benchmarks for the innovative methods but, in practice this may not be so. The accuracy of the Raman spectroscopy could not be fairly compared because the standard analytical method used in the studies we accessed was either not stated or was the high performance liquid chromatography (HPLC), which is outside the scope of this review. 


\section{Figures}

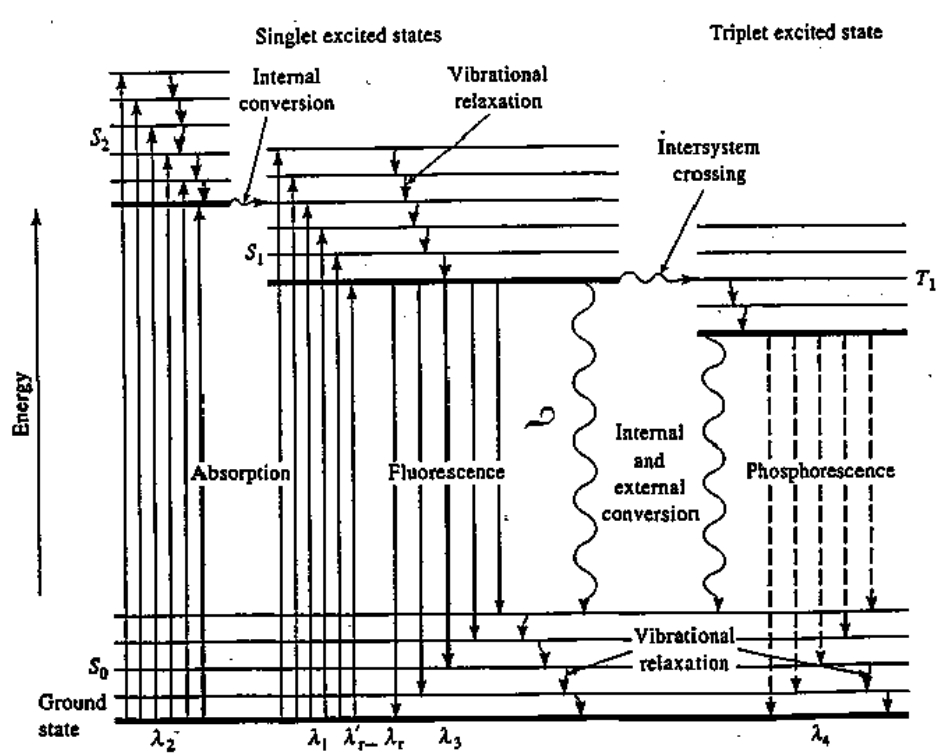

Figure 1: Electronic transition energy levels (Source: http://www.oswego.edu

\section{/ kadima/CHE425/CHE425L/FLUORESCENCE_SPECTROSCOPY_08.pdf)}

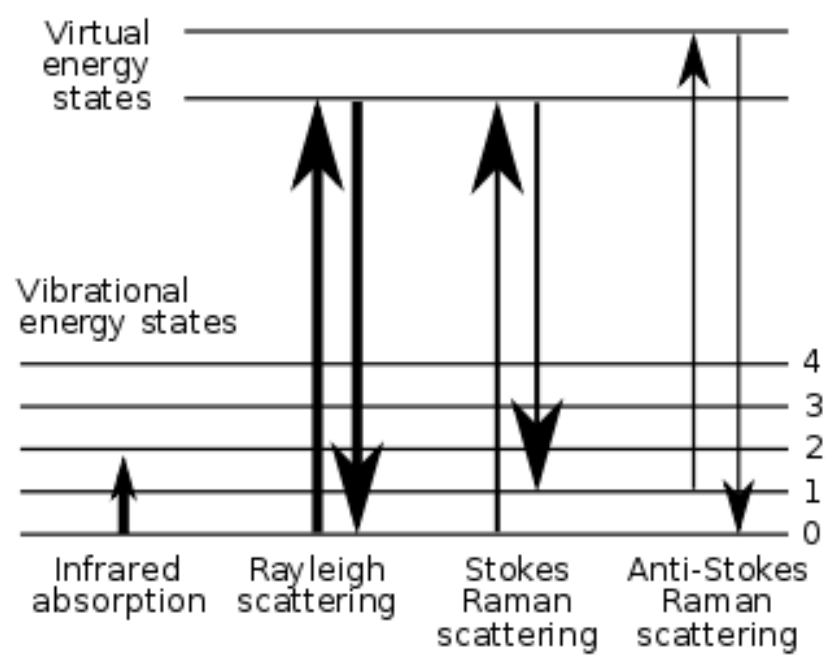

Figure 2: Energy level diagram for Raman scattering process (Source: Wikipedia, The Free Encyclopaedia: http://en.wikipedia.org/wiki/Raman_spectroscopy). The line thickness is roughly proportional to the signal strength from the different transitions. 
$\underline{\text { RE: Permission to use part of Table } 4 \text { (TPHCWG 1998, vol. 2) }}$

FROM:Brenna Lockwood

TO:'Reuben okparanma'

Message flagged

Wednesday, 14 December 2011, 14:52

Message Body

Reuben,

You have our permission to use the table for your review paper.

Thank you,

Brenna Lockwood

AEHS Foundation, Inc.

150 Fearing St., Suite 21

Amherst, MA 01002

413-549-5170 T

413-549-0579 F

brenna@aehsfoundation.org

www.aehsfoundation.org

From: Reuben okparanma [mailto:rokparanma@yahoo.com]

Sent: Tuesday, December 13, 2011 2:21 PM

To: orders@aehs.com

Subject: Permission to use part of Table 4 (TPHCWG 1998, vol. 2)

Dear Editor,

I am emailing to seek permission to use part of Table 4 in pages 20 and 21 in one of your publications: TPHCWG 1998, vol. 2. for a review paper intended to be submitted to the Environmental Science and Technology Journal.

Best wishes.

Reuben.

Reuben N. Okparanma,

Researcher, School of Applied Sciences, Cranfield University, MK43 OAL Bedfordshire, UK. r.okparanma@cranfield.ac.uk

01234-750111 ext 2793 